\title{
Audiomagnetotelluric Data and Preliminary Two-Dimensional Models from Spring, Dry Lake, and Delamar Valleys, Nevada
}

By Darcy K. McPhee, Bruce A. Chuchel, and Louise Pellerin

Prepared in cooperation with the Southern Nevada Water Authority

Open-File Report 2008-1301

U.S. Department of the Interior U.S. Geological Survey 


\section{U.S. Department of the Interior DIRK KEMPTHORNE, Secretary}

\section{U.S. Geological Survey \\ Mark D. Myers, Director}

U.S. Geological Survey, Reston, Virginia: 2008

For product and ordering information:

World Wide Web: http://www.usgs.gov/pubprod

Telephone: 1-888-ASK-USGS

For more information on the USGS - the Federal source for science about the Earth, its natural and living resources, natural hazards, and the environment:

World Wide Web: http://www.usgs.gov

Telephone: 1-888-ASK-USGS

Suggested citation:

McPhee, D.K., Chuchel, B.A., Pellerin, L., 2008, Audiomagnetotelluric data and preliminary two-dimensional models from Spring, Dry Lake, and Delamar Valleys, Nevada: U.S. Geological Survey Open-File Report 2008-1301, 59 p.

Any use of trade, product, or firm names is for descriptive purposes only and does not imply

endorsement by the U.S. Government.

Although this report is in the public domain, permission must be secured from the individual

copyright owners to reproduce any copyrighted material contained within this report. 


\section{Contents}



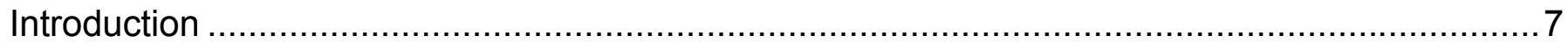

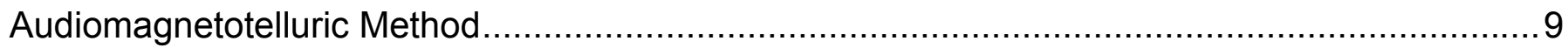

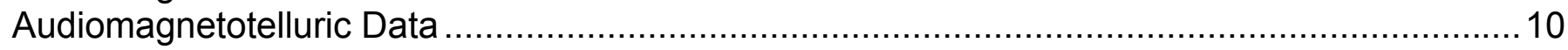

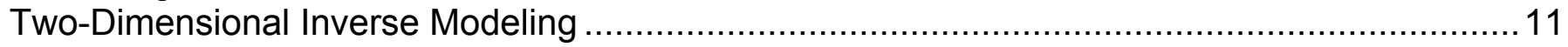

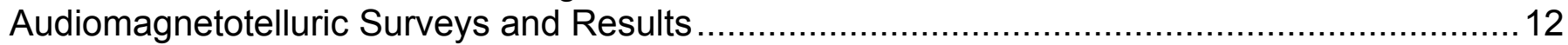

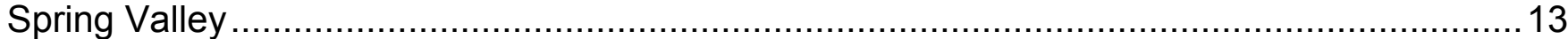

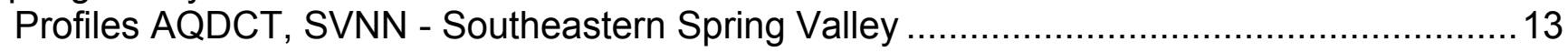

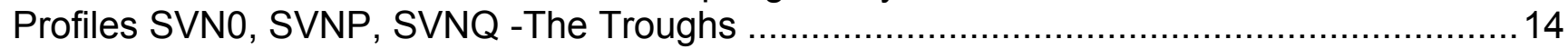

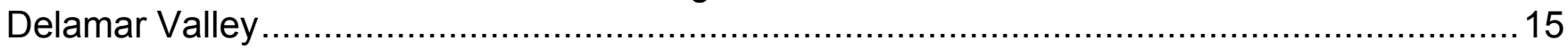

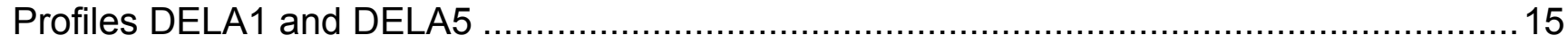

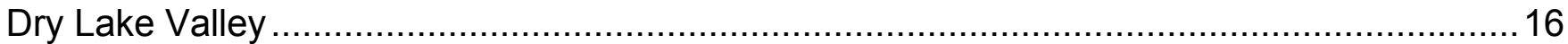

Profiles DLV1, DLV2, DLV3, DLV4, DLV5, DLV8, and DLV24 ..................................... 16

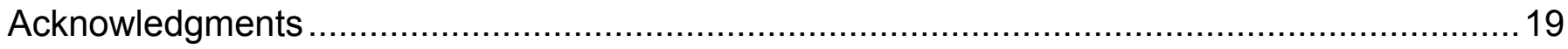



\section{Figures}

Figure 1. Topographic map of southern Spring Valley, Nev., showing location of audiomagnetotelluric profiles in red. Profiles shown in blue were collected prior to May 2007 and are presented in McPhee and others, 2006, 2007.

Figure 2. Topographic map of Delamar Valley, Nev., showing location of audiomagnetotelluric profiles in red.

Figure 3. Topographic map of Dry Lake Valley, Nev., showing audiomagnetotelluric profiles in red.

Figure 4. Two-dimensional inverse model computed from the transverse magnetic-mode data along profile AQDCT in Spring Valley, Nev. 25

Figure 5. Pseudosections of observed data and model response for the apparent resistivity and phase along profile AQDCT in Spring Valley, Nev. . ..............................26 Figure 6. Two-dimensional inverse model computed from the transverse magnetic-mode data along profile SVNN in Spring Valley, Nev. 27

Figure 7. Pseudosections of observed data and model response for the apparent resistivity and phase along profile SVNN in Spring Valley, Nev. ................................28

Figure 8. Two-dimensional inverse model computed from the transverse magnetic-mode data along profile SVNO in Spring Valley, Nev. 29

Figure 9. Pseudosections of observed data and model response for the apparent resistivity and phase along profile SVNO in Spring Valley, Nev. 30

Figure 10. Two-dimensional inverse model computed from the transverse magneticmode data along profile SVNP in Spring Valley, Nev.

Figure 11. Pseudosections of observed data and model response for the apparent resistivity and phase along profile SVNP in Spring Valley, Nev.

Figure 12. Two-dimensional inverse model computed from the transverse electric- and transverse magnetic-mode data along profile SVNQ in Spring Valley, Nev. 
Figure 13. Pseudosections of observed data and model response for the apparent resistivity and phase along profile SVNQ for both transverse electric- $(A)$ and transverse magnetic- (B) modes in Spring Valley, Nev.

Figure 14. Two-dimensional inverse model computed from the transverse magnetic-

mode data along profile DELA1 in Delamar Valley, Nev. .......................................... 35

Figure 15. Pseudosections of observed data and model response for the apparent resistivity and phase along profile DELA1 in Delamar Valley, Nev. ...............................36

Figure 16. Two-dimensional inverse model computed from the transverse magneticmode data along profile DELA5 in Delamar Valley, Nev.

Figure 17. Pseudosections of observed data and model response for the apparent resistivity and phase along profile DELA5 in Delamar Valley, Nev. . ............................38

Figure 18. Two-dimensional inverse model computed from the transverse magneticmode data along profile DLV1 in Dry Lake Valley, Nev.

Figure 19. Pseudosections of observed data and model response for the apparent resistivity and phase along profile DLV1 in Dry Lake Valley, Nev.

Figure 20. Two-dimensional inverse model computed from the transverse magneticmode data along profile DLV2 in Dry Lake Valley, Nev.

Figure 21. Pseudosections of observed data and model response for the apparent resistivity and phase along profile DLV2 in Dry Lake Valley, Nev.

Figure 22. Two-dimensional inverse model computed from the transverse magneticmode data along profile DLV3 in Dry Lake Valley, Nev.

Figure 23. Pseudosections of observed data and model response for the apparent resistivity and phase along profile DLV3 in Dry Lake Valley, Nev.

Figure 24. Two-dimensional inverse model computed from the transverse magneticmode data along profile DLV4 in Dry Lake Valley, Nev.

Figure 25. Pseudosections of observed data and model response for the apparent resistivity and phase along profile DLV4, Dry Lake Valley, Nev.

Figure 26. Two-dimensional inverse model computed from the transverse magneticmode data along profile DLV5 in Dry Lake Valley, Nev.

Figure 27. Pseudosections of observed data and model response for the apparent resistivity and phase along profile DLV5 in Dry Lake Valley, Nev.

Figure 28. Two-dimensional inverse model computed from the transverse electric- and transverse magnetic-mode data along profile DLV8 in Dry Lake Valley, Nev.....

Figure 29. Pseudosections of observed data and model response for the apparent resistivity and phase along profile DLV8 for both transverse electric- (A) and transverse magnetic- (B) modes in Dry Lake Valley, Nev.

Figure 30. Two-dimensional inverse model computed from the transverse magneticmode data along profile DLV24 in Dry Lake Valley, Nev.

Figure 31. Pseudosections of observed data and model response for the apparent resistivity and phase along profile DLV24 in Dry Lake Valley, Nev.

\section{Tables}

Table 1. Description of AMT profiles.

Table 2. Sounding numbers, locations, elevations and azimuths of stations along AMT profiles. 


\section{Appendix}

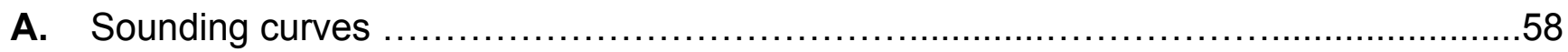






\title{
Audiomagnetotelluric Data and Preliminary Two-Dimensional Models from Spring, Dry Lake, and Delamar Valleys, Nevada
}

\author{
By Darcy K. McPhee ${ }^{1}$, Bruce A. Chuchel ${ }^{1}$, and Louise Pellerin ${ }^{2}$
}

\begin{abstract}
This report presents audiomagnetotelluric (AMT) data along fourteen profiles in Spring, Delamar, and Dry Lake Valleys, and the corresponding preliminary two-dimensional (2-D) inverse models. The AMT method is a valuable tool for estimating the electrical resistivity of the Earth over depth ranges from a few meters to less than one kilometer, and it is important for revealing subsurface structure and stratigraphy within the Basin and Range province of eastern Nevada, which can be used to define the geohydrologic framework of the region. We collected AMT data by using the Geometrics StrataGem EH4 system. Profiles were 0.7 - $3.2 \mathrm{~km}$ in length with station spacing of $50-400 \mathrm{~m}$. Data were recorded in a coordinate system parallel to and perpendicular to the regional geologic-strike direction with $\mathrm{Z}$ positive down. We show AMT station locations, sounding curves of apparent resistivity, phase, and coherency, and 2-D models of subsurface resistivity along the profiles. The 2-D inverse models are computed from the transverse electric (TE), transverse magnetic (TM), and TE+TM mode data by using a conjugate gradient, finite-difference method. Preliminary interpretation of the 2-D models defines the structural framework of the basins and the resistivity contrasts between alluvial basin-fill, volcanic units, and carbonate basement rocks.
\end{abstract}

\section{Introduction}

The Basin and Range province is an arid, mountainous, sparsely populated region of the western United States. Extensive regional systems (Harrill and Prudic, 1998) contain ground water that can flow between adjacent topographic ranges and basins. The location of basin-fill aquifers and carbonate rocks, and their hydraulic connectivity to the carbonate-rock aquifer system that underlies the entire eastern two-thirds of the Great Basin (Plume, 1996; Harrill and Prudic, 1998), is important for assessing ground-water resources in the region. Range-front faults are a primary

\footnotetext{
${ }^{1}$ U.S. Geological Survey, 345 Middlefield Rd., MS 989, Menlo Park, CA 94025

${ }^{2}$ Green Engineering, Inc., 2215 Curtis St., Berkeley, CA 94702
} 
structural control on the hydrogeology of the valleys in eastern Nevada. However, structure within the basins is often obscured by basin-fill sediments and, hence, geophysical investigations are needed to characterize the subsurface structures and stratigraphy influencing ground-water resources. The gravity method has been used to estimate the structure and depth of the basins in eastern Nevada (Mankinen and others, 2006, 2007, 2008; Scheirer, 2005), but because densities of volcanic rocks in the area may be comparable to the average density of basin sediment-fill, which is comprised of semi-consolidated to unconsolidated sand, gravel, silt, clay, and local evaporites, it may be difficult to resolve the subsurface geometry of the basin-fill and volcanic rocks by using the gravity method alone.

Previous audiomagnetotelluric (AMT) results from eastern Nevada (McPhee and others, 2006, 2007), including studies in Spring Valley, show that two-dimensional (2-D) inversion of AMT sounding data defines significant structure within the upper kilometer of the subsurface in a typical basin setting. Detailed structure was observed within alluvial basins, including clear transitions between unsaturated and saturated alluvium/volcanic rocks, high-resistivity (greater than 1,000 ohm-m) carbonate basement rocks, and the locations of range-front and intra-basin faults. In some cases AMT models defined the shape of and depth to the basement, which correlated well with depth to basement estimates derived from inversion of gravity data (Mankinen and others, 2006).

In this study, the AMT method is used in Spring, Delamar, and Dry Lake valleys, Nev., (figs. 1, 2, and 3) to define potential geologic/tectonic structures significant to ground-water resources. Several field surveys were conducted in Spring Valley during Spring/Summer of 2007 by using methods identical to those described in McPhee and others (2006, 2007). Subsequent surveys in Delamar and Dry Lake valleys were conducted between the Fall of 2007 and Spring of 2008. In all of these surveys we were able to delineate range-front faults, structure, and stratigraphy within the basins, as well as the overall framework of the basins. The models created in this study are being used to help site ground-water exploration wells and are contributing to the geologic framework for hydrologic modeling in the region.

The purpose of this report is to present the AMT sounding data and preliminary 2-D inverse models. Hydrogeologic interpretation of the models is not the focus of this report, and only general comments are made relative to geologic structure. 


\section{Audiomagnetotelluric Method}

The magnetotelluric (MT) method is a geophysical technique that uses the Earth's natural electromagnetic (EM) fields as a source to investigate the electrical resistivity structure of the subsurface (Telford and others, 1991; Vozoff, 1991). Within the upper crust, the resistivity of geologic units is largely dependent upon their fluid content, porosity, degree of fracturing, temperature, and conductive mineral content (Keller, 1989). Saline fluids within pore spaces and fracture openings can reduce bulk resistivities by several orders of magnitude relative to the dry rock matrix. Resistivity also can be lowered by the presence of conductive clay minerals, graphite, and metallic sulfide mineralization. Elevated temperatures, up to approximately $300{ }^{\circ} \mathrm{C}$, cause higher ionic mobility and mineral-activation energy, reducing rock resistivities significantly (Nesbitt, 1993). Unaltered, unfractured igneous rocks normally are resistive, with values typically 1,000 ohm-m or greater. Fault zones can appear as low resistivity units of less than $100 \mathrm{ohm}-\mathrm{m}$ when they are comprised of rocks fractured enough to host fluid transport and consequent mineralogical alteration (Eberhart-Phillips and others, 1995). Carbonate and clastic rocks are moderately to highly resistive, with values of hundreds to thousands of ohm-m depending upon their fluid content, porosity, fracturing, and impurities. Marine shale, mudstone, and clay-rich alluvium are normally very conductive, having values of a few to tens of ohm-m. Unaltered, metamorphic, nongraphitic rocks are moderately to highly resistive. Tables of electrical resistivity for a variety of rocks, minerals, and geological environments may be found in Keller (1987) and Palacky (1987).

By using the same theory as the MT method, the AMT method is used to estimate the electrical resistivity of the Earth over depth ranges of a few meters to about one kilometer, employing a higher frequency range (Zonge and Hughes, 1991). The resistivity can be estimated by using the electrical impedance, a tensor quantity defined by the ratio of time-varying electric (E) to magnetic $(\mathrm{H})$ field measured at the Earth's surface. The surface impedance is a complex function of frequency; higher-frequency data are used to investigate the near surface, and lowerfrequency data are used to investigate greater depths. For a 2-D Earth, the diagonal terms of the impedance tensor are zero, and the off-diagonal terms can be decoupled into transverse electric (TE) and transverse magnetic (TM) modes. When the geology satisfies the 2-D assumption, the data for the TE mode measure electric field parallel to geologic strike, and data for the TM mode measure electric field perpendicular to geologic strike. This 2-D assumption permits significant 
simplification in the modeling and inversion of MT and AMT data. Inversion of AMT sounding data provides an estimate of resistivity beneath the receiver site and indicates the geoelectric complexity at the measurement site. In areas where the resistivity distribution does not change rapidly from station to station, the resistivity sounding provides a reasonable estimate of the resistivity layering beneath the site.

The Geometrics StrataGem EH-4 system utilizes both natural- and controlled-source electromagnetic signals to obtain a continuous electrical sounding of the Earth beneath the measurement site (Geometrics, 2000). Data are recorded from 92,000 to $10 \mathrm{~Hz}$. The natural field strength is weak around $1,000 \mathrm{~Hz}$, so the controlled source is used to augment the natural field from $800 \mathrm{~Hz}$ to $56 \mathrm{kHz}$. The measurement site must be sufficiently far away from the controlled source, or transmitter, such that it is in the transmitter's far field, where a plane-wave impedance of the earth can be calculated (Geometrics, 2000). For each measurement, surface-impedance results are displayed as a resistivity sounding. Data are subsequently modeled by using a 2-D inversion algorithm (see section titled 2-D Inverse Modeling) for all of the sites along each AMT profile. A more thorough discussion of the Stratagem EH-4 system used in this study is contained in Geometrics (2000) and McPhee and others (2006).

\section{Audiomagnetotelluric Data}

After transforming the recorded time-series data to the frequency domain, EM transfer functions are estimated (Geometrics, 2000) from which the apparent resistivity and phase tensor can be calculated at each site. Apparent resistivity is impedance magnitude normalized by frequency and the magnetic susceptibility for free space. The apparent resistivity and phase are related through a Hilbert transform; the phase is proportional to the slope of the apparent resistivity curve on a log-log plot, relative to a baseline of 45 degrees (Vozoff, 1991).

Predicted values of the electric field can be computed from the measured values of the magnetic field (Vozoff, 1991). The coherence of the predicted electric field with the measured electric field is a measure of the signal-to-noise ratio and quality of the recorded data, and it is displayed as a function of frequency in the E-predicted coherency plots. Coherency values are between 0 and 1 , where values at 0.5 denote signal levels equal to noise levels.

Several soundings were recorded at each station. The best sounding from each station is presented (Appendix A) and used in subsequent modeling of the data. The unedited data presented 
here are not rotated to the local geologic strike, but are fixed at specific azimuths as acquired in the field (table 2). The ExHy measurement is the nominal TM mode, and the EyHx measurement is the nominal TE mode. Tensor data are calculated by using Imagem software (Geometrics, 2000). For each station, three separate panels are displayed in Appendix A: (1) apparent resistivity, (2) impedance phase, and (3) coherency. AMT data are available in two formats: Geometrics Z Impedance files (Geometrics, 2000; Appendix A) and the Electronic Data Interchange (EDI), which was established in 1987 by the Society of Exploration Geophysicists (SEG) as a standard format for the interchange of MT data (Wright, 1988).

\section{Two-Dimensional Inverse Modeling}

Before modeling, impedance tensor data along each profile were rotated such that the $\mathrm{E}$ and $\mathrm{H}$ fields were approximately parallel and perpendicular to the regional geologic strike in the area. Based on the trends of faulting and geologic structures in these valleys, as well as depth to basement maps derived from gravity data, we chose our profiles in most cases to run roughly perpendicular to the geologic strike. Based on the 2-D nature of the geologic structures in all three valleys, we were fairly certain that we were working in 2-D environments. However, in some cases 3-D effects in the data were likely. Once mathematically rotated, spurious data and data with coherencies less than 0.75 were removed prior to inversion.

Dimensionality of each profile was determined by inspecting the data. Even in the presence of 3-D effects, 2-D modeling of the TM mode has been shown to be a robust approach (Wannamaker and others, 1984). We compute 2-D inverse models from the TE, TM, and TE+TM mode data by using the conjugate gradient, finite-difference inversion of Rodi and Mackie (2001) for a range of starting models with many variations of regularization and smoothing parameters (Geosystem, 2005). We computed inversion models, both with and without topography, and determined that the topography, which was fairly modest along each profile, did not affect the model results. Several starting models were used to test model sensitivity and the depth of investigation. In addition, one-dimensional (1-D) models were calculated to test depth sensitivity at each station. The primary criteria for choosing final models included the goodness of fit of the model response to the data as reported by a root mean square (RMS) measure, the lack of artifacts in the model not supported by the data, and geological reasonableness of the model. RMS commonly is used to express the misfit between data and the model response. Misfits are 
normalized by the data error, or the applied error floor. Misfits for the presented models typically have RMS values between 2 and 3, which are representative of a reasonable fit of the data to the model response.

The AMT data on each profile also are displayed in pseudosection format with distance on the horizontal axis and period, the inverse of frequency, on the vertical axis (for example, see fig. 5). As frequency is a nonlinear proxy for depth, pseudosections represent qualitatively the variation of apparent resistivity and phase with depth. The calculated apparent resistivity and phase from the inverse model response is displayed for comparison and is used to judge the goodness of fit. Our preferred models represent the most robust results along each line and use the cleanest data. Although the depth of exploration varies as a function of resistivity and frequency, we display a constant depth of investigation throughout each section to represent the approximate average depth of investigation along the entire profile. In all cases, we incorporate topography in the final inversions.

\section{Audiomagnetotelluric Surveys and Results}

This section discusses details of each AMT survey, as well as the 2-D models along each line. AMT data was collected in cooperation with the Southern Nevada Water Authority (SNWA) by teams of three to four people led by either the USGS or SNWA (table 1). Three separate surveys were conducted in Spring Valley (fig. 1). Two profiles (AQDCT and SVNN) were collected in May and September 2007, respectively, across the southeastern margin of Spring Valley. Three additional profiles (SVNO, SVNP, SVNQ) were collected in southern Spring Valley in June 2007 in an area known as the Troughs, which marks the region between Spring and Hamlin valleys (fig. 1). Two additional profiles (DELA1, DELA5) of AMT data were collected in southern Delamar Valley during three field sessions between November 2007 and February 2008 (fig. 2). Finally, seven profiles (DLV1, DLV2, DLV3, DLV4, DLV5, DLV8, DLV24) of AMT data were collected in Dry Lake Valley between September 2007 and April 2008 (fig. 3). A description of each AMT profile is provided in table 1, and individual sounding-location information is contained in table 2.

Overall, the AMT 2-D models define range-front and interbasin faults, basin-fill alluvium, volcanic rocks, and carbonate and clastic rocks. All interpretations presented here are preliminary, however, and are based on simple observations of the initial models. 


\section{Spring Valley}

\section{Profiles AQDCT, SVNN - Southeastern Spring Valley}

Profiles AQDCT and SVNN were in the southeastern region of Spring Valley and extended from the Snake Range into the valley (fig. 1). Profile AQDCT ran along a $3 \mathrm{~km}$-long line perpendicular to the north-northwest trending range front and parallel to the Harbeck Aqueduct, which was approximately $450 \mathrm{~m}$ to the north. In addition to the aqueduct, potential sources of electromagnetic noise included power lines several kilometers away. Noise sources, such as power lines, power generators, and moving vehicles and trains, produce noise mainly affecting frequencies above $1 \mathrm{~Hz}$, including the AMT observation frequency band. However, data quality along AQDCT was good, and only one station had to be removed (sounding \#24) due to noisy high frequency (greater than $1 \mathrm{kHz}$ ) data.

The data along this line were determined to be quasi-1-D in character, where structure varies slowly from that of a layered Earth. A 2-D Earth assumes that there is no variation along the strike direction. Faulted structures can be strongly 2-D or quasi-1-D depending on the offset. In either case, a 2-D inversion strategy is justified. Our preferred 2-D inverse model along line AQDCT was computed from the TM-mode data and a $250 \mathrm{ohm}-\mathrm{m}$ starting half-space with topography (figs. 4 and 5). There is a transition between more resistive (approximately 1,000 ohm$\mathrm{m}$ ) rocks at depth along the eastern end of the line to a more conductive region in the west, possibly indicative of the transition from crystalline basement rock in the east to more conductive valley fill sediments toward the west.

Profile SVNN extends along a 2.4-km-long line that extends east-west for about $1 \mathrm{~km}$ and then turns to the southeast for the remainder of the line (fig. 1). A N-S trending power line was approximately $600 \mathrm{~m}$ to the west of the westernmost sounding (\#47) along this line, therefore, the low-frequency data at the westernmost stations (soundings \#47 and \#35) were noisier than at other stations, but overall data quality was good. Sounding \#23 was removed due to noisy highfrequency data. The El Tejon Shoshone Spring, showing a water-table depth of roughly $50 \mathrm{~m}$ (SNWA, oral commun., September 2007), is approximately $100 \mathrm{~m}$ north of sounding \#21.

Our preferred model along SVNN was computed from the TM mode data and a $100 \mathrm{ohm}-\mathrm{m}$ half-space starting model with topography (figs. 6 and7). Data were rotated such that the xdirection was $80^{\circ}$ magnetic and perpendicular to the north-trending range front, and we assumed two-dimensionality along this profile. Due to the bend in this profile, models were run separately 
along two different azimuth profiles, as well as along one best fit, east-west line. The bend in the line did not affect the model results, and our final model is the result of stations projected onto one best-fit line. There is a sharp contrast between more resistive, inferred basement rocks at the eastern end of the line and more conductive valley-fill sediments at the western end of the line. This transition likely indicates a steeply dipping range-front fault, however; it is not clear whether we are at the basin margin, or simply approaching it, and the resistivity of the 'basement rock' along SVNN is less than that observed at depth at the east end of AQDCT (Note the difference in the resistivity scales in figs. 4 and 6). There is no indication of water level based on the known depth of the water table in this area (roughly $50 \mathrm{~m}$ ), which might be expressed as a subtle resistivity contrast at that depth; however, 50-m depth is likely at the shallow resolution limit of our model.

\section{Profiles SVN0, SVNP, SVNQ -The Troughs}

Profiles SVNO, SVNP, and SVNQ were in southeastern Spring Valley near the Troughs, the area between Spring and Hamlin valleys. For the most part, this region is devoid of anthropogenic noise sources and is an ideal area for AMT-data collection. Profile SVNO is a short line $(1.2 \mathrm{~km})$ and extends southwest from the volcanic rocks of the Red Ledges into the valley. Although this line is oblique to the overall north-south geologic strike of the Snake Range and Limestone Hills further to the south, it is perpendicular to the local volcanic outcrops that characterize the Red Ledges, and we assume two-dimensionality along this short profile. SVNO intersects Profile SVNP to the south, and we included a sounding from SVNP (sounding \#14) in our modeling. Data quality was very good along SNVO.

Our preferred model along SVNO was computed from the TM mode data and a $50 \mathrm{ohm}-\mathrm{m}$ half-space starting model (figs. 8 and 9). A $50 \mathrm{ohm}-\mathrm{m}$ half-space starting model was preferred over more resistive starting models, possibly indicative of the more conductive volcanic setting, as opposed to the more resistive limestone basement rocks along the other AMT lines in Spring Valley that are presented here. The model along SVNO shows a gradual transition between a conductive (roughly $5 \mathrm{ohm}-\mathrm{m}$ ) region, near the Red Ledges (in the northeast), to slightly more resistive (roughly $15 \mathrm{ohm}-\mathrm{m}$ ) areas further into the valley (in the southwest). As compared to models further north (AQDCT, SVNN), this section of the southeastern margin of Spring Valley is more conductive.

Profile SVNP extends along a $3 \mathrm{~km}$-long east-west line directly through the Troughs region (fig. 1). Although SVNP is in a saddle region between the Red Ledges to the north and the 
Limestone Hills to the south, the profile azimuth roughly is perpendicular to the regional strike of range-front faults in the valley, which we are attempting to image here. Other than some scrap metal and a small buried pipe near sounding \#5, there were no human-made noise sources, and data quality was excellent.

The preferred 2-D model along SVNP was computed from TM-mode data and a $100 \mathrm{ohm}-\mathrm{m}$ half-space starting model (figs. 10 and 11). Preliminary interpretation indicates the sharp transition between resistive (greater than $400 \mathrm{ohm}-\mathrm{m}$ ) and more conductive (20 ohm-m) regions near sounding \#5 likely marks the location of a fault separating limestone rocks to the east with more conductive valley fill or volcanic rocks to the west. Another possible fault is near sounding \#37 at the eastern end of the profile, possibly marking another contact between more conductive volcanic rocks and more resistive carbonate rocks.

Further to the south of SVNP, profile SVNQ runs along a $2 \mathrm{~km}$-long transect perpendicular to the western margin of the Limestone Hills (fig. 1). Data were rotated such that the positive xazimuth was aligned with the east-west strike of the profile. Data quality was excellent, and no artificial sources of noise were present. Our preferred model along SVNQ was computed from both the TE and TM mode data and a $100 \mathrm{ohm}-\mathrm{m}$ half-space starting model with topography (figs. 12 and 13). Although resulting models for the TE+TM modes and the TM mode only were similar, the TE+TM mode model is preferred because it is more representative of the geology of the Limestone Hills region. A clear transition between resistive rocks of the Limestone Hills and more conductive valley-fill sediments is located sharply between sounding \#12 and \#14, likely indicative of a range-front fault.

The AMT models in the Troughs region of Spring Valley represent three different geologic settings. The AMT models show clear regional transitions from more conductive volcanic rocks associated with Red Ledges along SVNO to more resistive basement rocks of the Limestone Hills (SVNQ). Profile SVNP shows the region in between and clearly images carbonate/volcanic contacts.

\section{Delamar Valley}

\section{Profiles DELA1 and DELA5}

The two AMT profiles collected in Delamar Valley were in the extreme southern part of Delamar Valley and attempted to image structures/faults near its southern margin (fig. 2). Profile 
DELA1 was a short $1.2 \mathrm{~km}$-long transect that extended roughly perpendicular to the range front. Power lines were less than $1 \mathrm{~km}$ away from the northernmost end of the line. Overall, data were a little noisy along the entire line, and the station furthest north and closest to the power lines was not used due to noise.

Profile DELA5 was a short $(0.7 \mathrm{~km})$ line located north and sub-parallel to DELA1 (fig. 2). DELA5 was oriented perpendicular to several shear zones that cut through the valley in the region that we were trying to image. However, DELA5 was oriented parallel to normal faulting in the area and sub parallel to the regional geologic strike, and it is unclear as to whether a suitable 2-D model is possible. Although no significant sources of noise existed along this line, data were very noisy and, overall data quality was poor.

Our preferred models along both DELA1 and DELA5 were computed from the TM mode data by using a $100 \mathrm{ohm}-\mathrm{m}$ half-space starting model with topography. The 2D model along DELA1 (figs. 14 and 15) shows two conductors separated by a less conductive region. While there is definitely structure within the basin, there is no clear demarcation of the basin margin. The 2-D model along DELA5 shows a lower resistivity section in the middle of the profile, possibly indicative of a tectonic shear zone; however, more in-depth dimensionality analysis and possibly data collection are necessary before further interpretation.

\section{Dry Lake Valley}

\section{Profiles DLV1, DLV2, DLV3, DLV4, DLV5, DLV8, and DLV24}

We collected our final seven AMT profiles in Dry Lake Valley (fig. 3), which is immediately north of Delamar Valley and about $200 \mathrm{~km}$ south of Spring Valley. DLV1 was the southernmost profile in Dry Lake Valley, and it extends approximately east-west along a $2 \mathrm{~km}$-long transect perpendicular to the north-south geologic strike of the valley. Data were rotated such that the positive $\mathrm{x}$-direction was in line with the profile azimuth; however, the far eastern end of the profile was in a saddle area with range fronts both to the north and south of the line, possibly contributing to $3 \mathrm{D}$ distortions. A N-S power line was roughly $600 \mathrm{~m}$ to the west of the western end of the line. In addition, one of the poles of the Stratagem transmitter was broken, which may have distorted the size of the magnetic moment and subsequent power transmitted from one of the loops. Overall, data quality was good, and the TM mode data was less noisy than TE mode data. 
Our preferred model along DLV1 was computed from the TM-mode data by using a 100 ohm-m half-space starting model with topography (figs. 18 and 19). There is a sharp transition near sounding \#24 between more resistive (greater than $500 \mathrm{ohm}-\mathrm{m}$ ) basement rocks to the east and more conductive (10 ohm-m) valley fill sediments to the west. There also is structure within the more resistive unit to the east from which we may preliminarily infer several range-front faults.

Profile DVL2 was a shorter $(1 \mathrm{~km})$ line at the extreme northern end of Dry Lake Valley (fig. 3). This line was oriented perpendicular to the range front and extended onto carbonate outcrops at the northeastern end of the line. There were no sources of artificial noise in this part of the valley. Low frequency $(10-800 \mathrm{~Hz})$ data quality was good; however, at stations close to and on top of carbonate rocks, high-frequency data quality was poor, likely due to the fact that the transmitter did not have enough power to enhance the weak natural signal at distances far enough away to escape the near-field. In addition, sounding \#25 was removed in the preferred model because the station was immediately next to an outcropping structure that likely was producing 3-D distortions in the data. Our preferred model along DLV2 was computed from the TM mode data and a $100 \mathrm{ohm}-\mathrm{m}$ half-space starting model with topography (figs. 20 and 21). We observe a clear transition between the more resistive carbonate rocks to the northeast and the more conductive valley-fill sediments to the southwest, although data coverage in the southwest is sparse.

Profile DLV3 was a $2 \mathrm{~km}$-long line south of DLV2 along the northeastern margin of Dry Lake Valley (fig. 3). DLV3 was oriented perpendicular to the basin margin and range-front, although the line did not extend all the way onto outcropping basement rocks in the northeast. There were no artificial sources of noise in the area. Data quality was good in the low-frequency range $(10-800 \mathrm{~Hz})$, but was poor at frequencies greater than $800 \mathrm{~Hz}$, possibly due to low power from the transmitter. Our preferred model was computed from TM-mode data by using a $100 \mathrm{ohm}$ $\mathrm{m}$ half-space starting model with topography (figs. 22 and 23). There is a clear transition between more resistive rocks to the northeast and more conductive rocks to the southwest that agrees with the change in topography as the profile moved from a slope, onto the playa at the southwest part of the line. More conductive rocks are associated with the playa and an interbasin fault may exist at the southwestern end of the profile.

Profile DLV4 is south of DLV3 along the eastern margin of Dry Lake Valley, and it extends along a $3.2 \mathrm{~km}$-long line that runs approximately perpendicular to the $\mathrm{N}-\mathrm{S}$ geologic strike of the valley. There were no obvious sources of artificial noise other than an old farm approximately 600 
$\mathrm{m}$ west of sounding \#3, which may house scrap metal and unknown underground pipes. In some cases the TE-mode data were noisier than the TM-mode data, and overall data quality was poor along this line. The preferred model along DLV4 was calculated from TM-mode data by using a $100 \mathrm{ohm}-\mathrm{m}$ half-space starting model with topography (figs. 24 and 25). This 2D model shows a transition from more resistive basement rocks in the east to more conductive valley fill in the west. Valley-fill conductivities are slightly less than what is observed along DLV3 further to the north. There is also a subtle resistivity high between sounding \#12 and \#42, possibly indicative of a contact or fault within the basin.

Profile DLV5 is north of DLV4 along the eastern margin of Dry Lake Valley, and it extends $1 \mathrm{~km}$ east-west perpendicular to the range-front. Data were rotated such that the positive $\mathrm{x}$ direction was in line with the profile azimuth. The profile extended to within a couple hundred meters of carbonate outcrops of the range-front to the east. There were no significant sources of artificial noise near the profile other than a metal fence with wooden posts that extended northsouth between soundings \#14 and \#17. Data quality, especially at frequencies greater than 1,000 $\mathrm{Hz}$, was poor along the entire line. Our preferred model along DLV5 was computed from the TMmode data by using a $100 \mathrm{ohm}-\mathrm{m}$ half-space starting model with topography (figs. 26 and 27). Due to noisy high-frequency data, our model does not resolve much detail in the upper few hundreds of meters (see lack of data points in fig. 27). There is a smooth transition between resistive carbonate rocks to the east and more conductive valley fill to the west.

Profile DLV8 is further to the south along the eastern margin of Dry Lake Valley between DLV1 and DLV4 (fig. 3). DLV8 extends along a $2.5 \mathrm{~km}$-long east-west line that is perpendicular to the range-front to the east. Other than a fence, there were no artificial noise sources. Data quality was relatively good, though the data were noisier at higher frequencies. Our preferred 2D model was calculated from both the TE- and TM-mode data by using a $100 \mathrm{ohm}-\mathrm{m}$ half-space starting model with topography (figs. 28 and 29). Equivalent models resulted by using the TMmode data only, with a slightly higher RMS fit. The 2D model along DLV8 shows resistive carbonate rocks to the east and more conductive alluvial fill to the west. A mapped fault (Keith Pari, written commun., March 2008) that extends north-south is just east of sounding \#7 where we observe a steeply dipping conductor in the subsurface. Another potential fault within the alluvium could exist near sounding \#2 based on initial interpretation. The model along DLV8 clearly delineates structure within the basin fill. 
Finally, profile DLV24 is a short profile $(1.4 \mathrm{~km})$ in the northwestern margin of Dry Lake Valley (fig. 3). DLV24 extends roughly perpendicular to the NE-SW trending volcanic range and crosses several NE-SW trending concealed faults (Todd Gurnee, written commun., April 2008). There were no significant sources of artificial noise in the area. All data along this line were rotated such that the x-positive direction was in line with the geologic strike of $25^{\circ}$ (relative to magnetic north). Data quality was good. A model was computed by using both the TE- and TM-mode data and a $100 \mathrm{ohm}-\mathrm{m}$ half-space starting model with topography. This model subsequently served as the starting model for a TM-mode-only inversion, which resulted in our preferred 2D model (figs. 30 and 31). A steep resistivity contrast is evident between soundings \#4 and $\# 8$ at the eastern end of the line, from which we can infer a contact between volcanic rocks or alluvial fill to the west and carbonate rocks to the east. Possible concealed faults exist roughly near sounding \#14 and between soundings \#12 and \#10, based on subtle, vertical resistivity gradients at these locations.

\section{Acknowledgments}

This study was performed in cooperation with the Southern Nevada Water Authority whose support is greatly appreciated. We are grateful to the many people that helped us in the field, including Melissa Cansdale, Brent Clark, Celia Coleman, Dave Culp, Eric Dano, Denise DeRossett, Harvey Eastman, Todd Gurnee, Aron Habte, Derik Howard, Paul Kuvelis, Randy Kyes, Jason Mace, Erin Orozco, Keith Pari, Jeff Sanchez, and Ray Schluth. We thank the staff of Geometrics for providing valuable and efficient field assistance, and we especially thank Gary Dixon for his continuing support and expertise. We also thank Ed Mankinen and Dan Scheirer for their helpful reviews.

\section{References Cited}

Eberhart-Phillips, D., Stanley, W.D., Rodriguez, B.D., and Lutter, W.J., 1995, Surface seismic and electrical methods to detect fluids related to faulting: Journal of Geophysical Research, v. 100, p. $12,919-12,936$.

Geometrics, 2000, Operation manual for Stratagem systems running IMAGEM, Ver. 2.16:

Geometrics, San Jose, California.

Geosystem, 2005, A guide to using WinGLink, Ver 2.07.05: Geosystem srl, Milan, Italy. 
Harrill, J.R., and Prudic, D.E., 1998, Aquifer systems in the Great Basin region of Nevada, Utah and adjacent states-Summary report: U.S. Geological Survey Professional Paper, 1409A, 61 p.

Keller, G.V., 1987, Rock and mineral properties, in Nabighian, M.N., ed., Electromagnetic methods in applied geophysics theory: Tulsa, Okla., Society of Exploration Geophysicists, Tulsa, v.1, p. $13-51$.

Keller, G.V., 1989, Electrical properties, in Carmichael, R.S., ed., Practical handbook of physical properties of rocks and minerals: Boca Raton, Florida, CRC Press, p. 359-427.

Mankinen, E.A., Chuchel, B.A., and Moring, B.C., 2008, Gravity data from Dry Lake and Delamar Valleys, east-central Nevada: U.S. Geological Survey Open-File Report 2008-1299, in press.

Mankinen, E.A., Roberts, C.W., McKee, E.H., Chuchel, B.A., and Morin, R.L., 2007, Geophysical data from Spring Valley to Delamar Valley, east-central Nevada: U.S. Geological Survey OpenFile Report 2007-1190, 43 p.

Mankinen, E.A., Roberts, C.W., McKee, E.H., Chuchel, B.A., and Moring, B.C., 2006, Geophysical data from the Spring and Snake valleys area, Nevada and Utah: U.S. Geological Survey Open-File Report 2006-1160, 42 p.

McPhee, D.K., Chuchel, B.A., and Pellerin, L, 2006, Audiomagnetotelluric data from Spring, Cave, and Coyote Spring Valleys, Nevada: U.S. Geological Survey Open-File Report 2006-1164, 41 p.

McPhee, D.K., Chuchel, B.A., and Pellerin, L., 2007, Audiomagnetotelluric data and twodimensional models from Spring, Snake, and Three Lakes Valleys, Nevada: U.S. Geological Survey Open-File Report 2007-1181, 47 p.

Nesbitt, B.E., 1993, Electric resistivities of crustal fluids, Journal of Geophsyical Research, v. 98, p. 4301-4310.

Palacky, G.J., 1987, Resistivity characteristics of geologic targets, in Nabighian, M.N., ed., Electromagnetic methods in applied geophysics theory: Tulsa, Okla., Society of Exploration Geophysicists, v. 1, p. 53-129.

Plume, R.W., 1996, Hydrogeologic framework of the Great Basin region of Nevada, Utah and adjacent states: U.S. Geological Survey Professional Paper 1409-B, 64 p.

Rodi, W., and Mackie, R. L., 2001, Nonlinear conjugate gradients algorithm for 2-D magnetotelluric inversion: Geophysics, v. 66, p. 174-187.

Scheirer, D.S., 2005, Gravity studies of Cave, Dry Lake, and Delamar Valleys, east-central Nevada: U.S. Geological Survey Open-File Report, 2005-1339, 36 p. 
Telford, W.M., Geldart, L.P., and Sheriff, R.E., 1991, Applied geophysics (2d ed.): Cambridge, Cambridge University Press, 790 p.

Vozoff, K., 1991, The magnetotelluric method, in Nabighian, M.N., ed., Electromagnetic methods in applied geophysics: Tulsa, Okla., Society of Exploration Geophysicists, v. 2, part B, p. 641711.

Wannamaker, P.E., Hohmann, G.W., and Ward, S.H., 1984, Magnetotelluric responses of threedimensional bodies in layered earths: Geophysics, v. 49, p. 1517-1533.

Wright, D.E., 1988, The SEG standard for magnetotelluric data: presented at the Society of Exploration Geophysicists Annual Meeting, November. [http://www.geophysics.dias.ie/mtnet/docs/ediformat.txt]

Zonge, K.L., and Hughes, L.J., 1991, Controlled source audio-frequency magnetotellurics, in Nabighian, M.N., ed., Electromagnetic methods in applied geophysics: Tulsa, Okla., Society of Exploration Geophysicists, v. 2, part B, p. 713-809. 


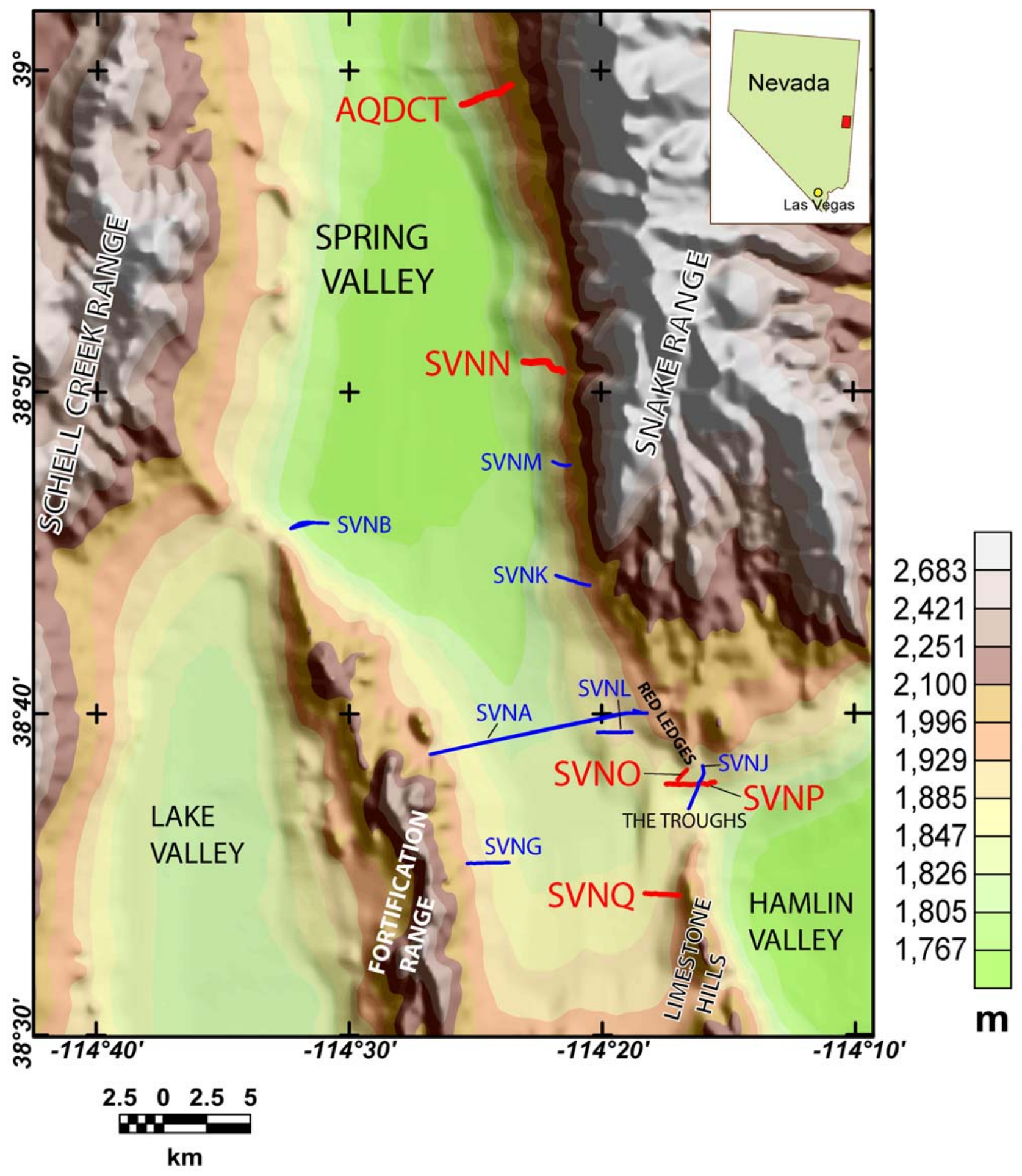

Figure 1. Topographic map of southern Spring Valley, Nev., showing location of audiomagnetotelluric profiles in red. Profiles shown in blue were collected prior to May 2007 and are presented in McPhee and others, 2006, 2007. 

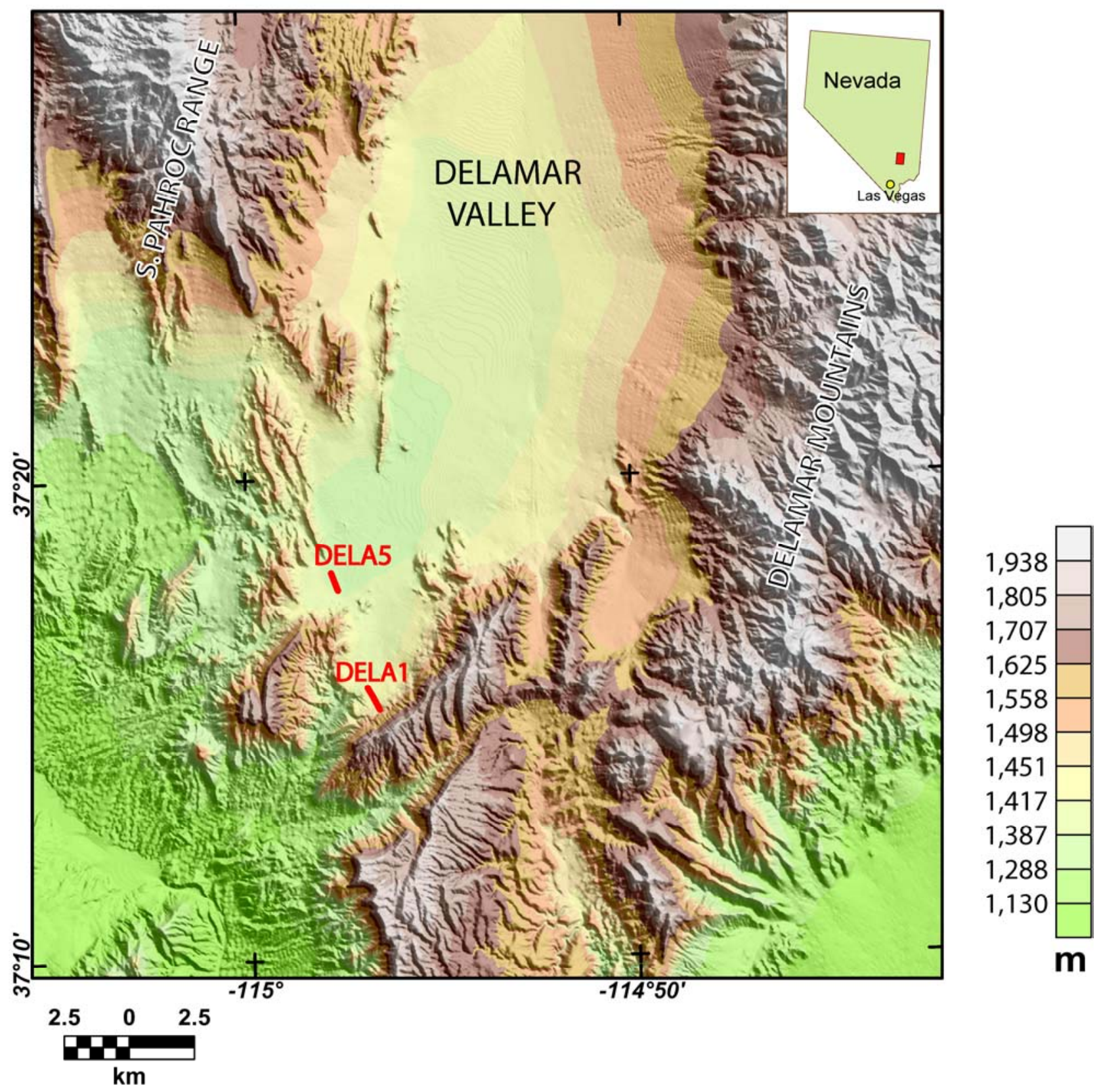

Figure 2. Topographic map of Delamar Valley, Nev., showing location of audiomagnetotelluric profiles in red. 




Figure 3. Topographic map of Dry Lake Valley, Nev., showing audiomagnetotelluric profiles in red. 




Figure 4. Two-dimensional inverse model computed from the transverse magnetic-mode data along profile AQDCT in Spring Valley, Nev. RMS $=2.9$. 


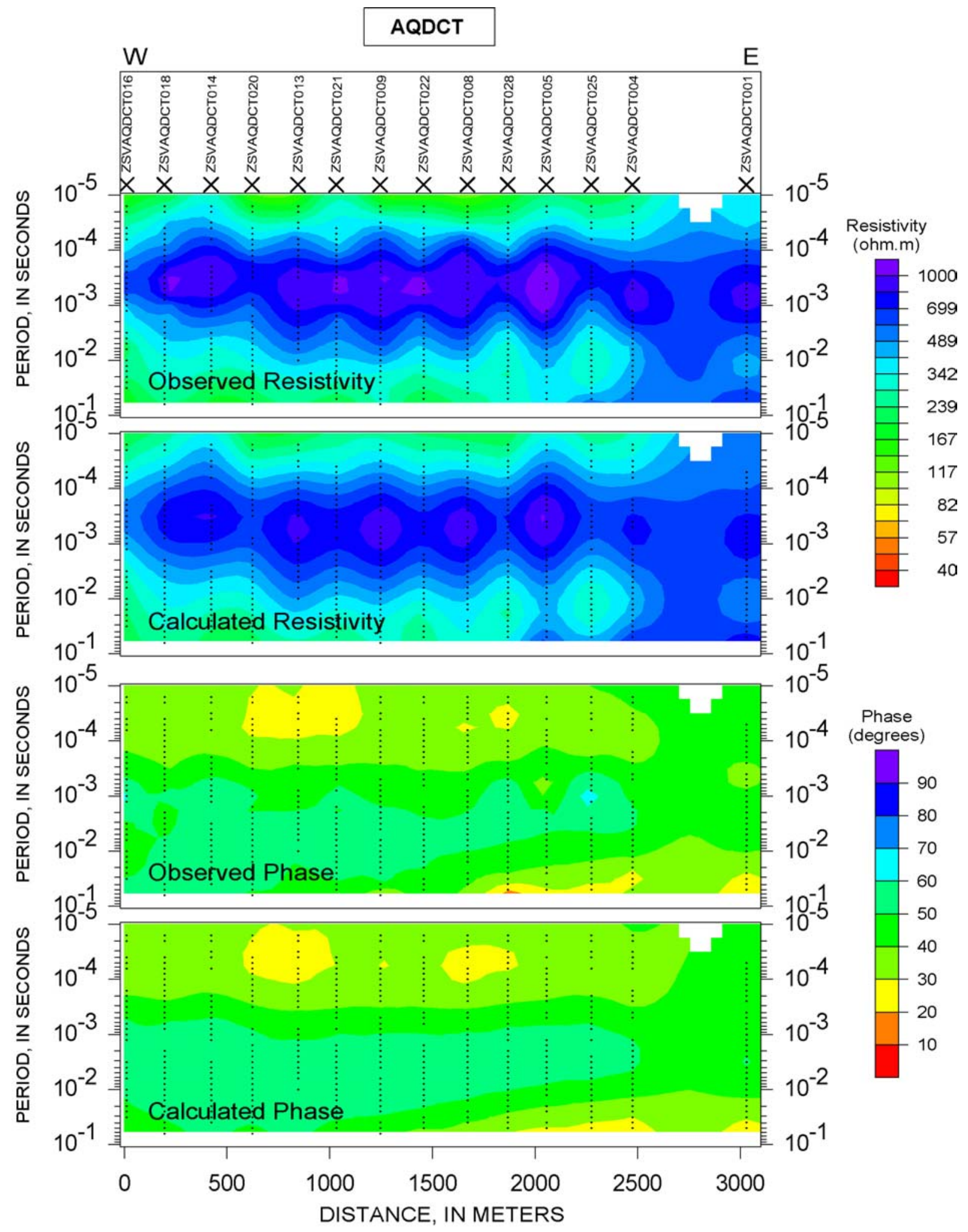

Figure 5. Pseudosections of observed data and model response for the apparent resistivity and phase along profile AQDCT in Spring Valley, Nev. Black dots show data points. 


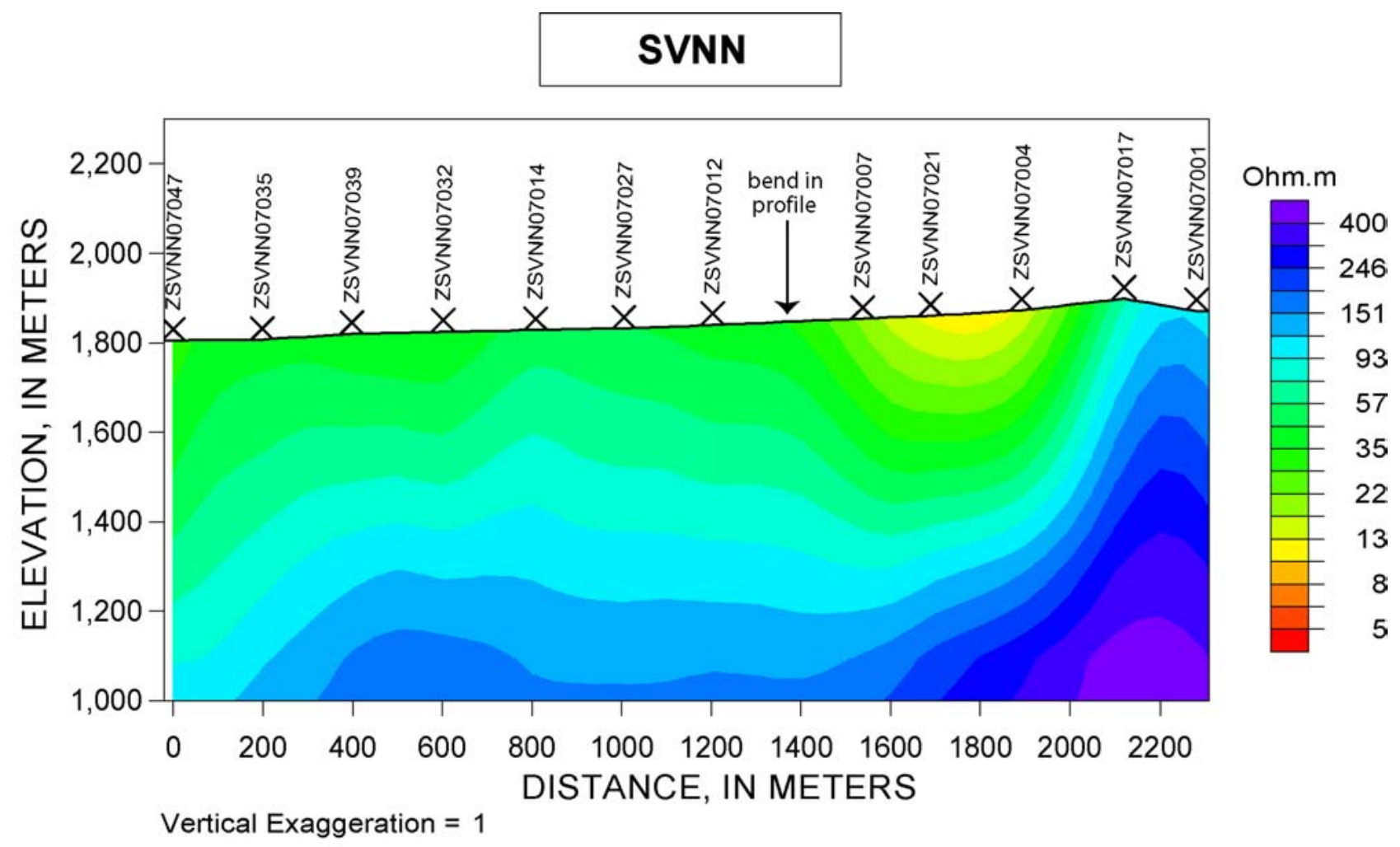

Figure 6. Two-dimensional inverse model computed from the transverse magnetic-mode data along profile SVNN in Spring Valley, Nev. RMS $=3.1$. Note change in resistivity scale from Figure 4. 


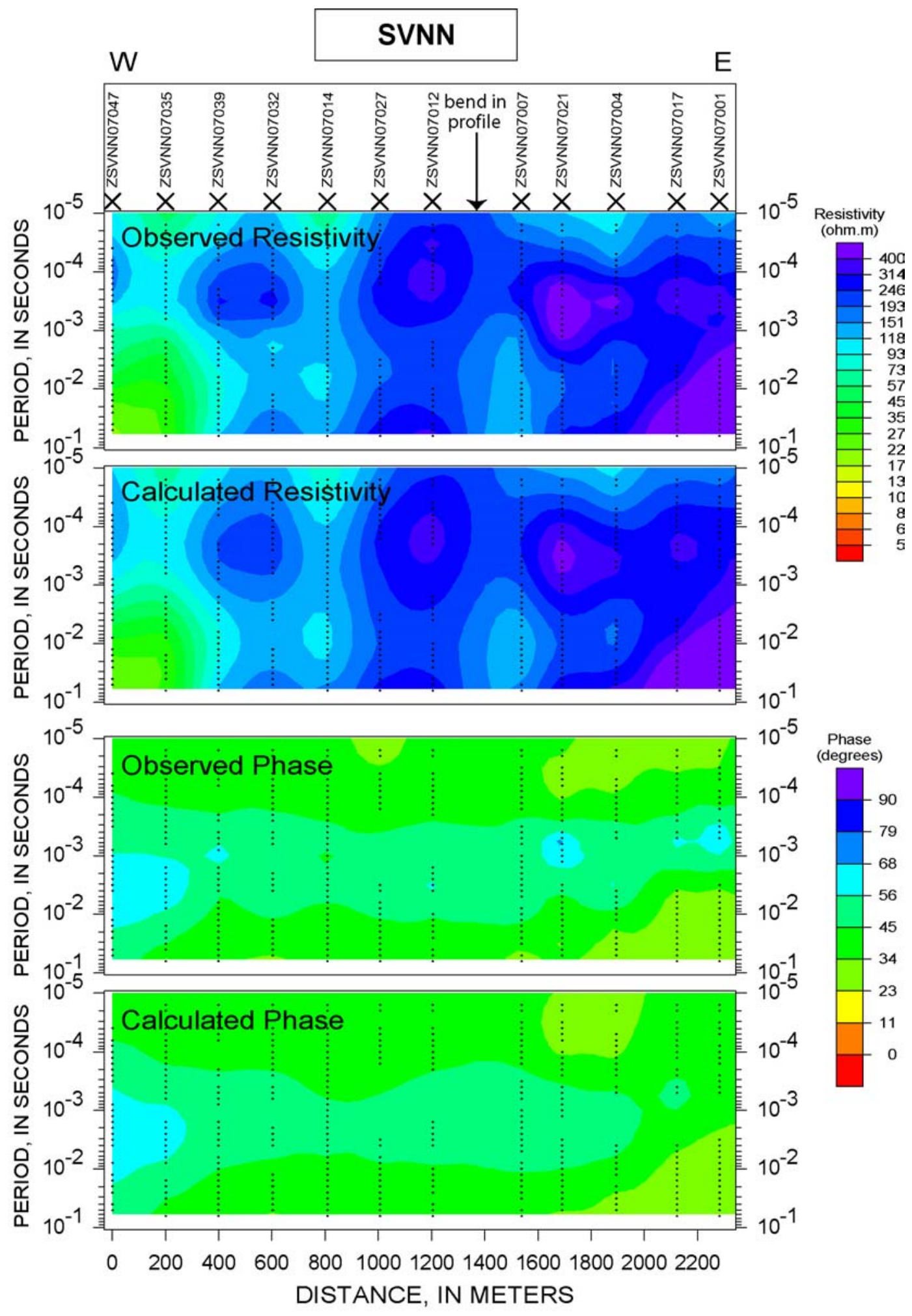

Figure 7. Pseudosections of observed data and model response for the apparent resistivity and phase along profile SVNN in Spring Valley, Nev. Black dots show data points. 




Figure 8. Two-dimensional inverse model computed from the transverse magnetic-mode data along profile SVNO in Spring Valley, Nev. RMS $=2.8$. 


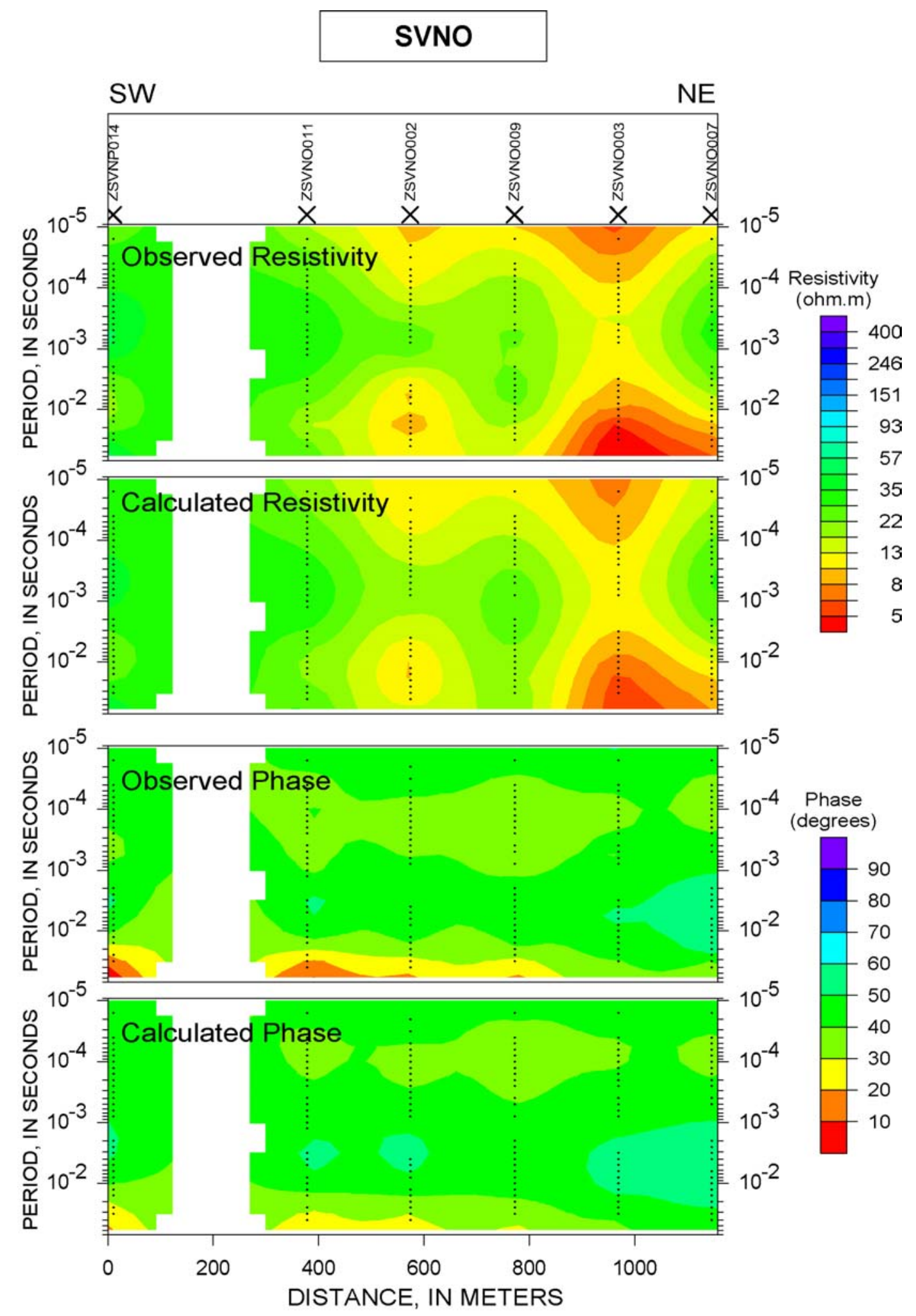

Figure 9. Pseudosections of observed data and model response for the apparent resistivity and phase along profile SVNO in Spring Valley, Nev. Black dots show data points. 


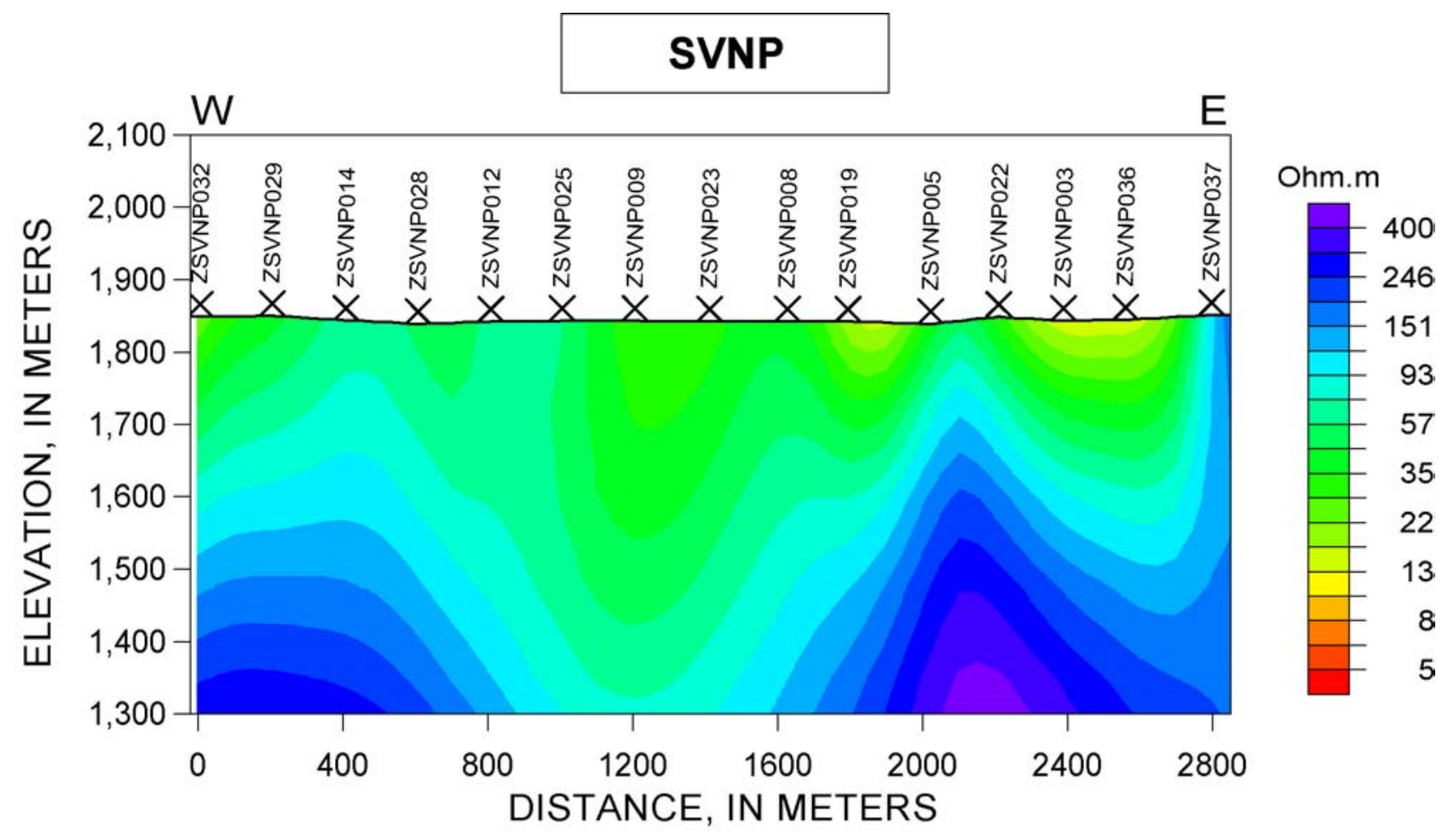

Vertical Exaggeration $=2$

Figure 10. Two-dimensional inverse model computed from the transverse magneticmode data along profile SVNP in Spring Valley, Nev. RMS $=2.5$. 


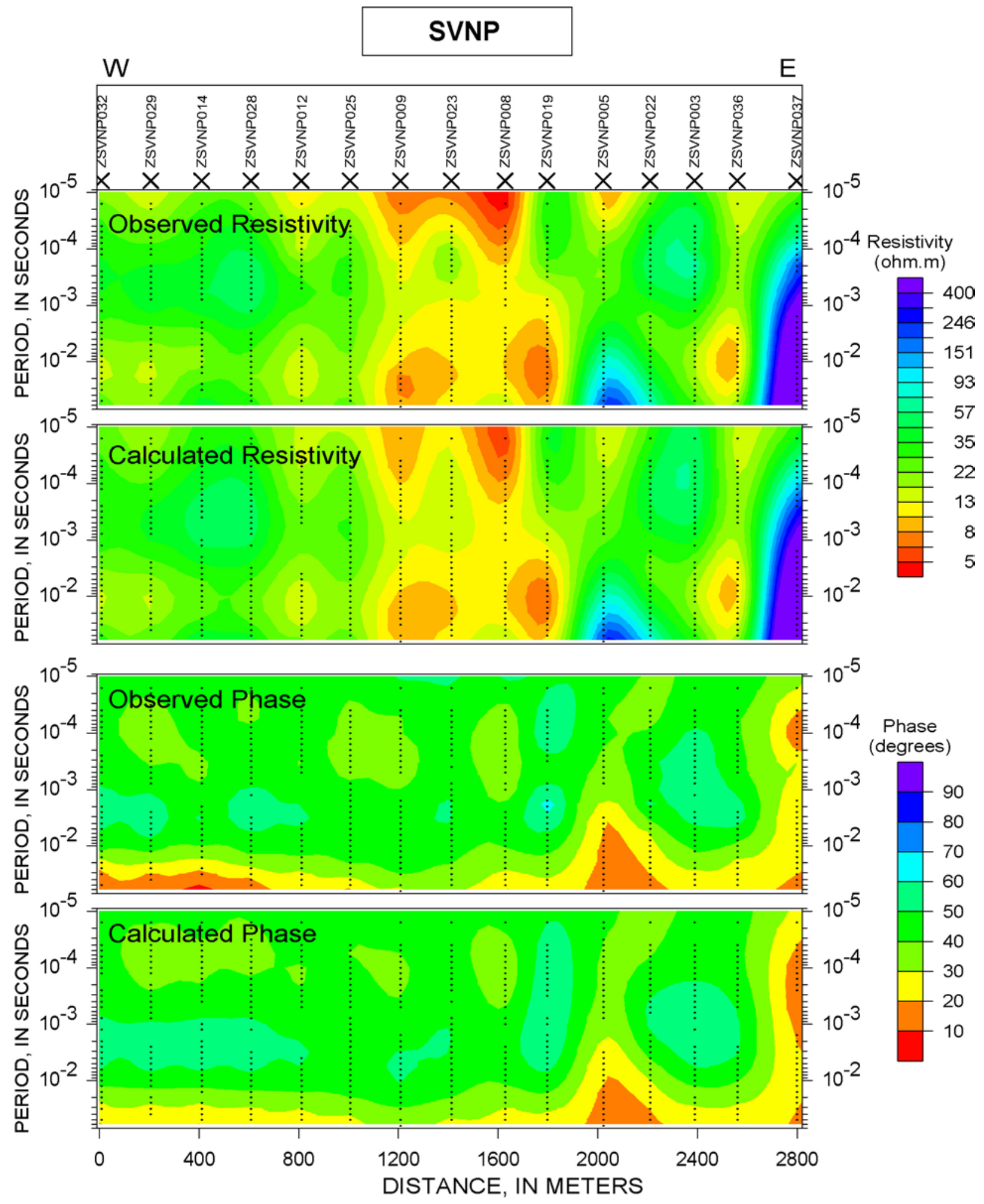

Figure 11. Pseudosections of observed data and model response for the apparent resistivity and phase along profile SVNP in Spring Valley, Nev. Black dots show data points. 


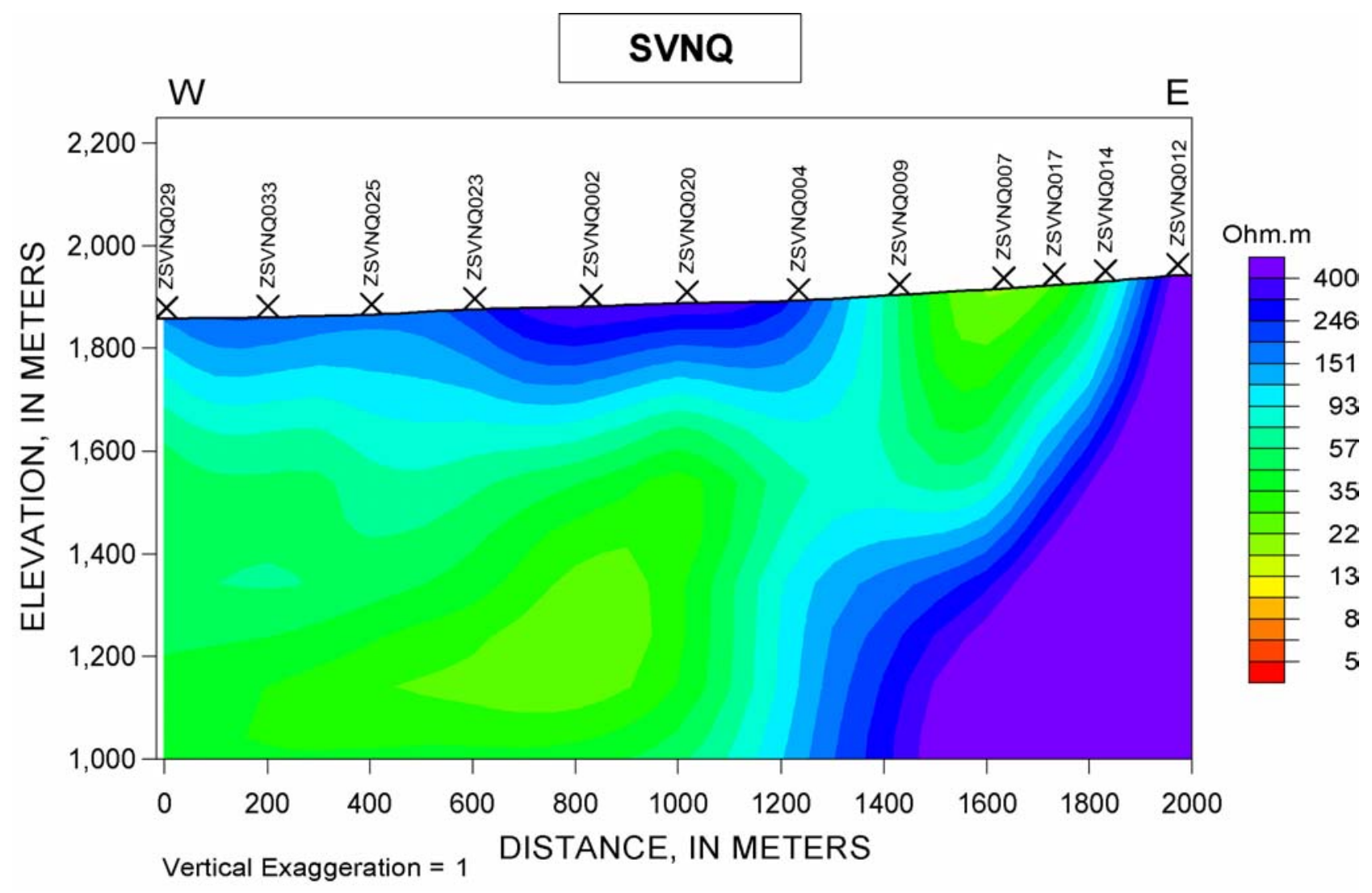

Figure 12. Two-dimensional inverse model computed from the transverse electric- and transverse magnetic-mode data along profile SVNQ in Spring Valley, Nev. RMS $=3.8$. 




A.
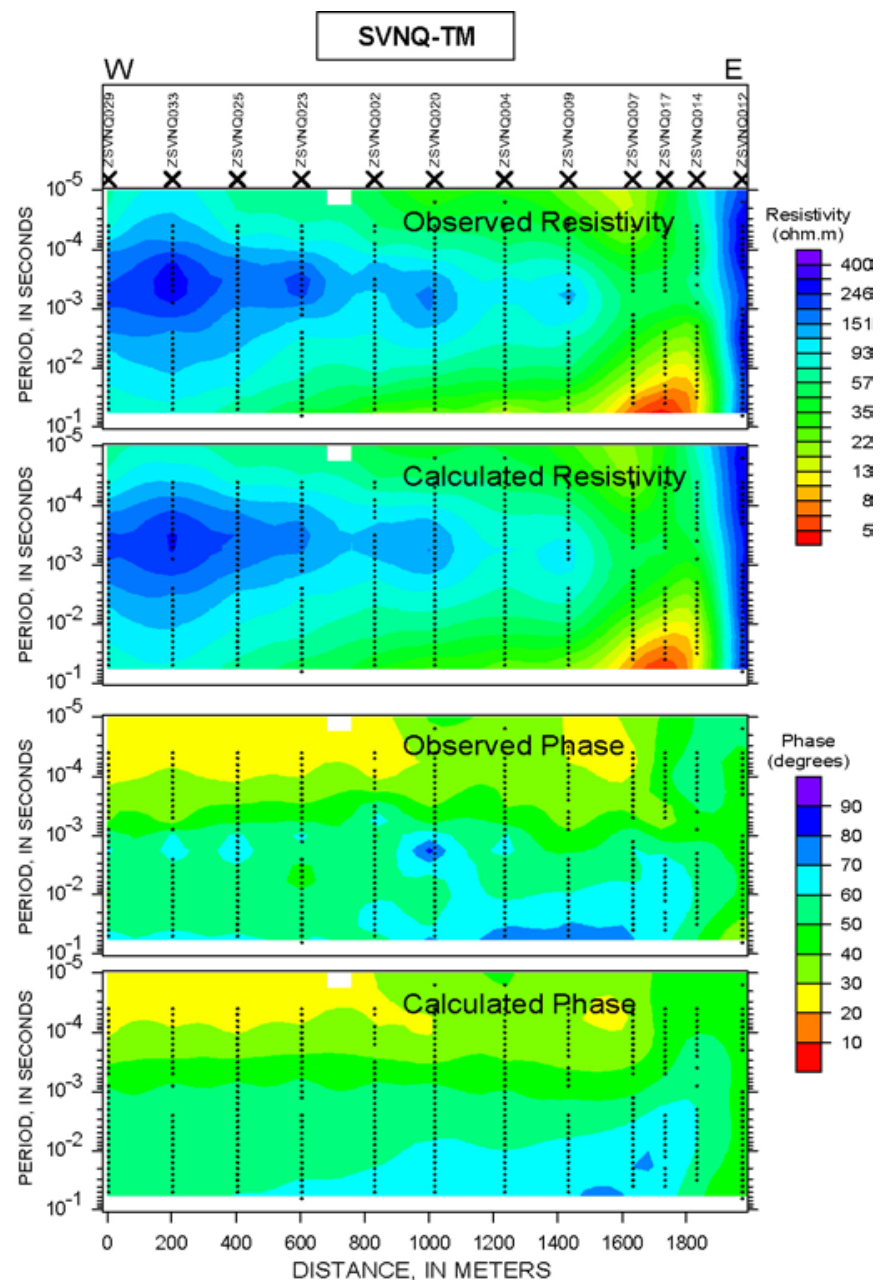

B.

Figure 13. Pseudosections of observed data and model response for the apparent resistivity and phase along profile SVNQ for both transverse electric- $(A)$ and transverse magnetic- (B) modes in Spring Valley, Nev. Black dots show data points. 


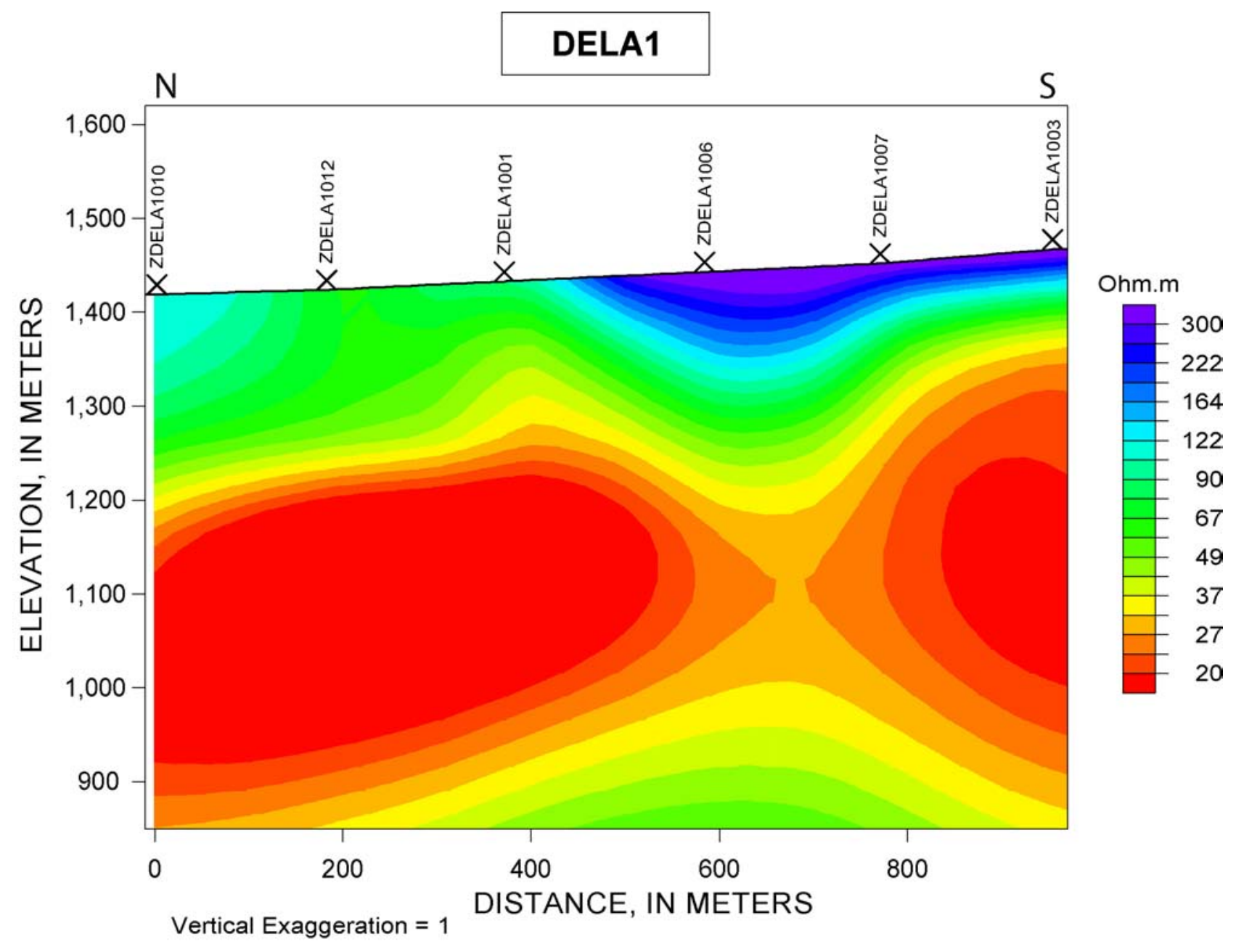

Figure 14. Two-dimensional inverse model computed from the transverse magneticmode data along profile DELA1 in Delamar Valley, Nev. RMS $=3.5$. Note that resistivity scale differs from that used in Spring Valley models. 




Figure 15. Pseudosections of observed data and model response for the apparent resistivity and phase along profile DELA1 in Delamar Valley, Nev. Black dots show data points. 




Figure 16. Two-dimensional inverse model computed from the transverse magneticmode data along profile DELA5 in Delamar Valley, Nev. RMS $=3.0$. 


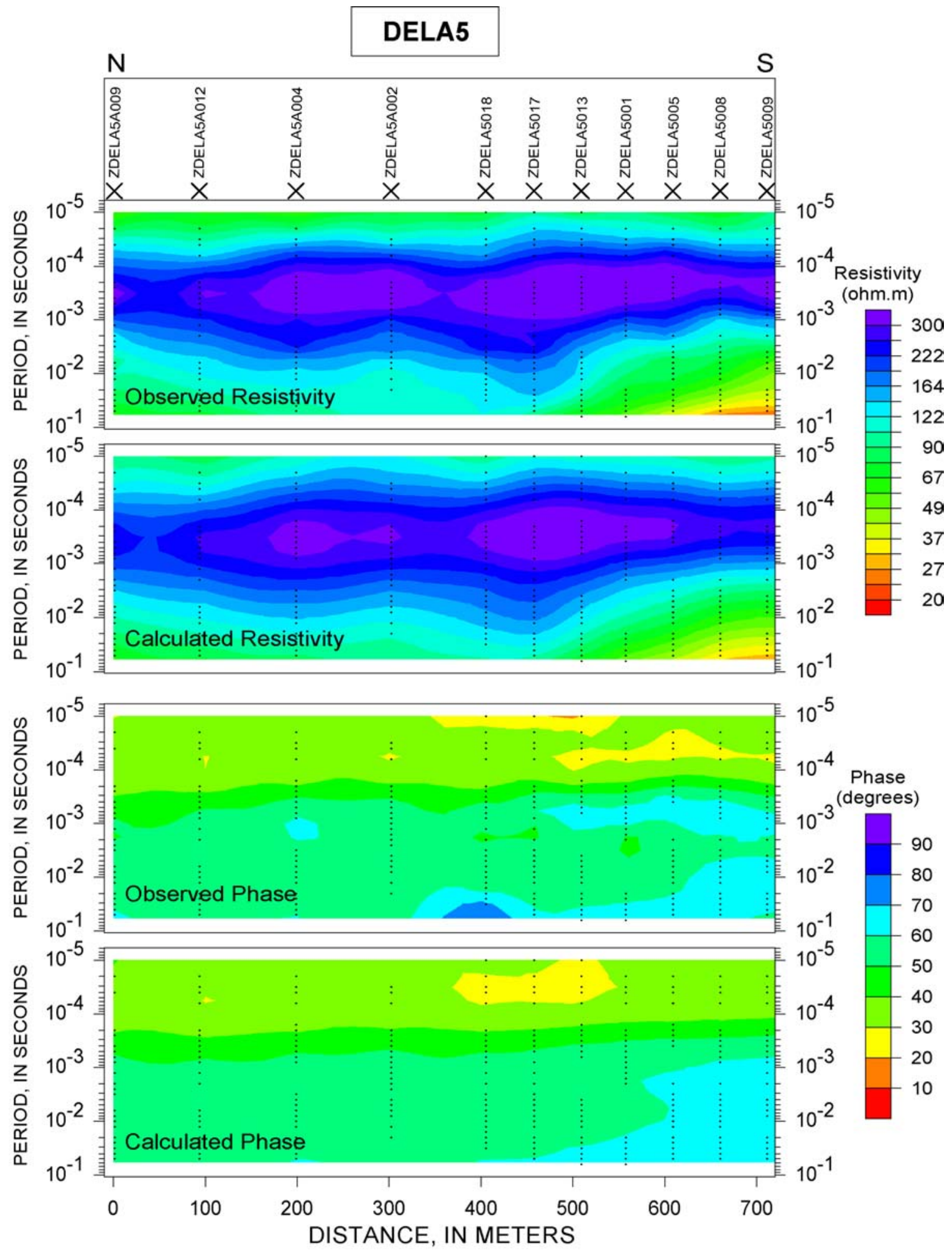

Figure 17. Pseudosections of observed data and model response for the apparent resistivity and phase along profile DELA5 in Delamar Valley, Nev. Black dots show data points. 


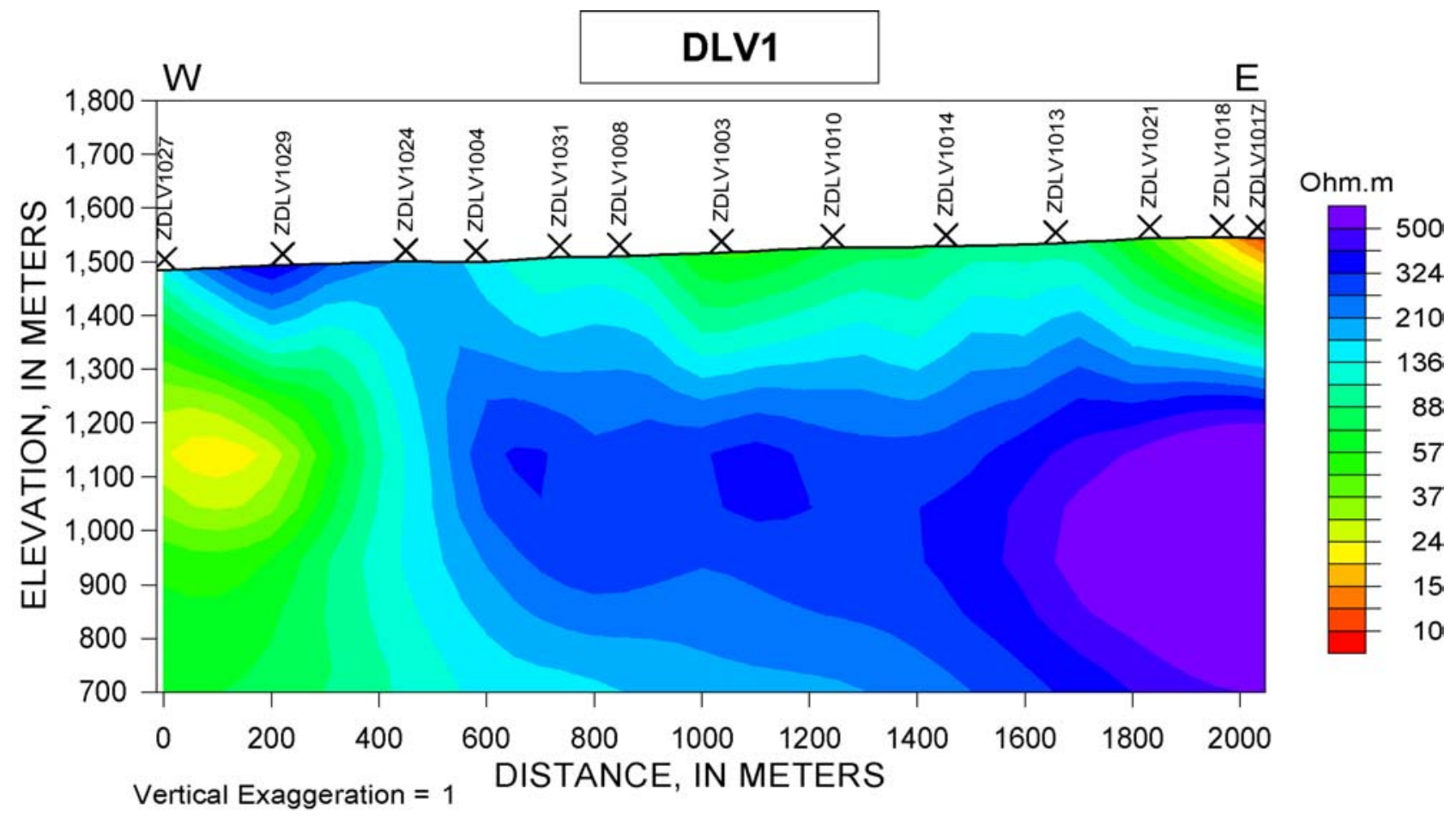

Figure 18. Two-dimensional inverse model computed from the transverse magneticmode data along profile DLV1 in Dry Lake Valley, Nev. RMS $=3.2$. Note that resistivity scale is different from that used in Spring Valley and Delamar Valley models. 




Figure 19. Pseudosections of observed data and model response for the apparent resistivity and phase along profile DLV1 in Dry Lake Valley, Nev. Black dots show data points. 


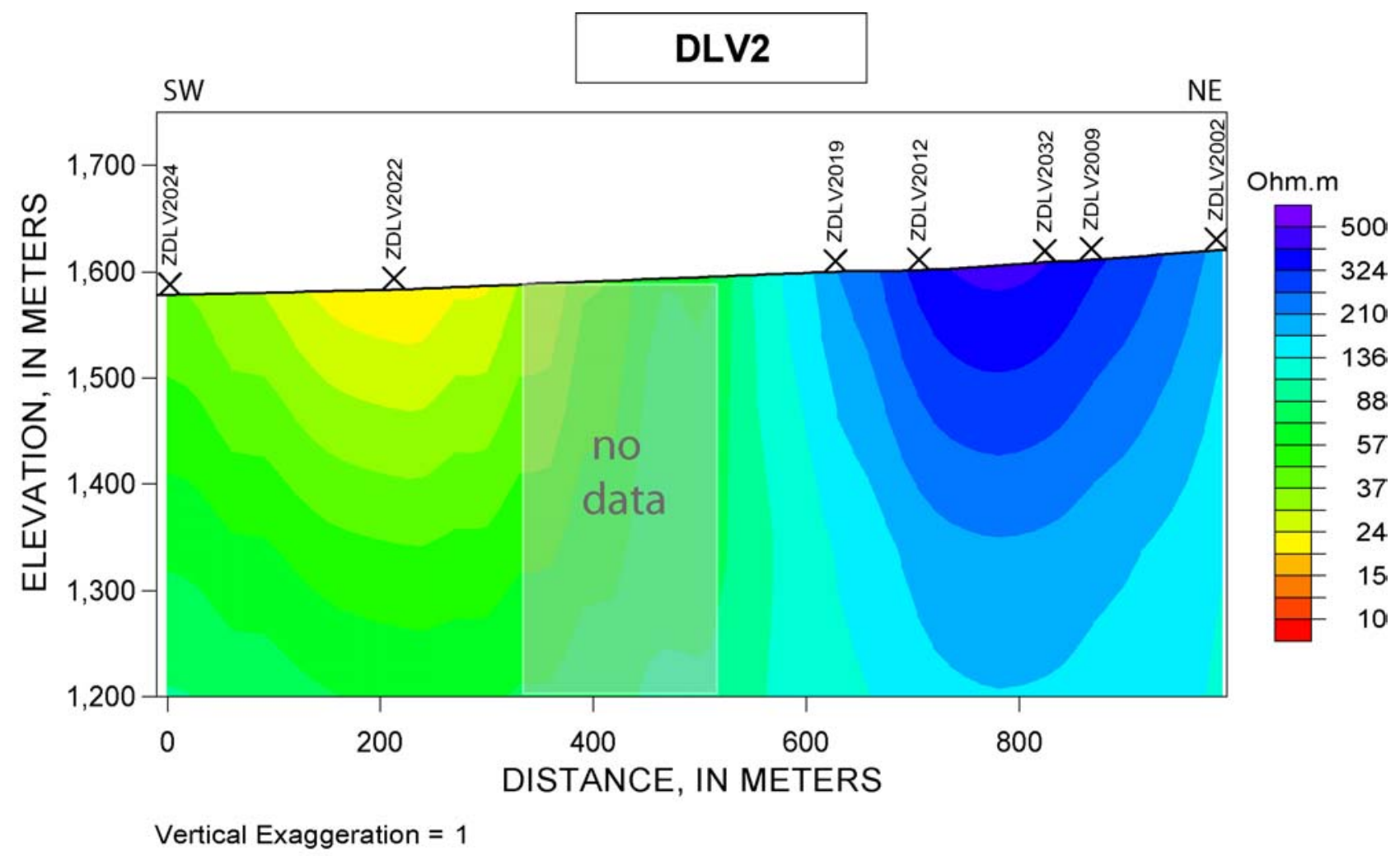

Figure 20. Two-dimensional inverse model computed from the transverse magneticmode data along profile DLV2 in Dry Lake Valley, Nev. RMS = 3.5. 


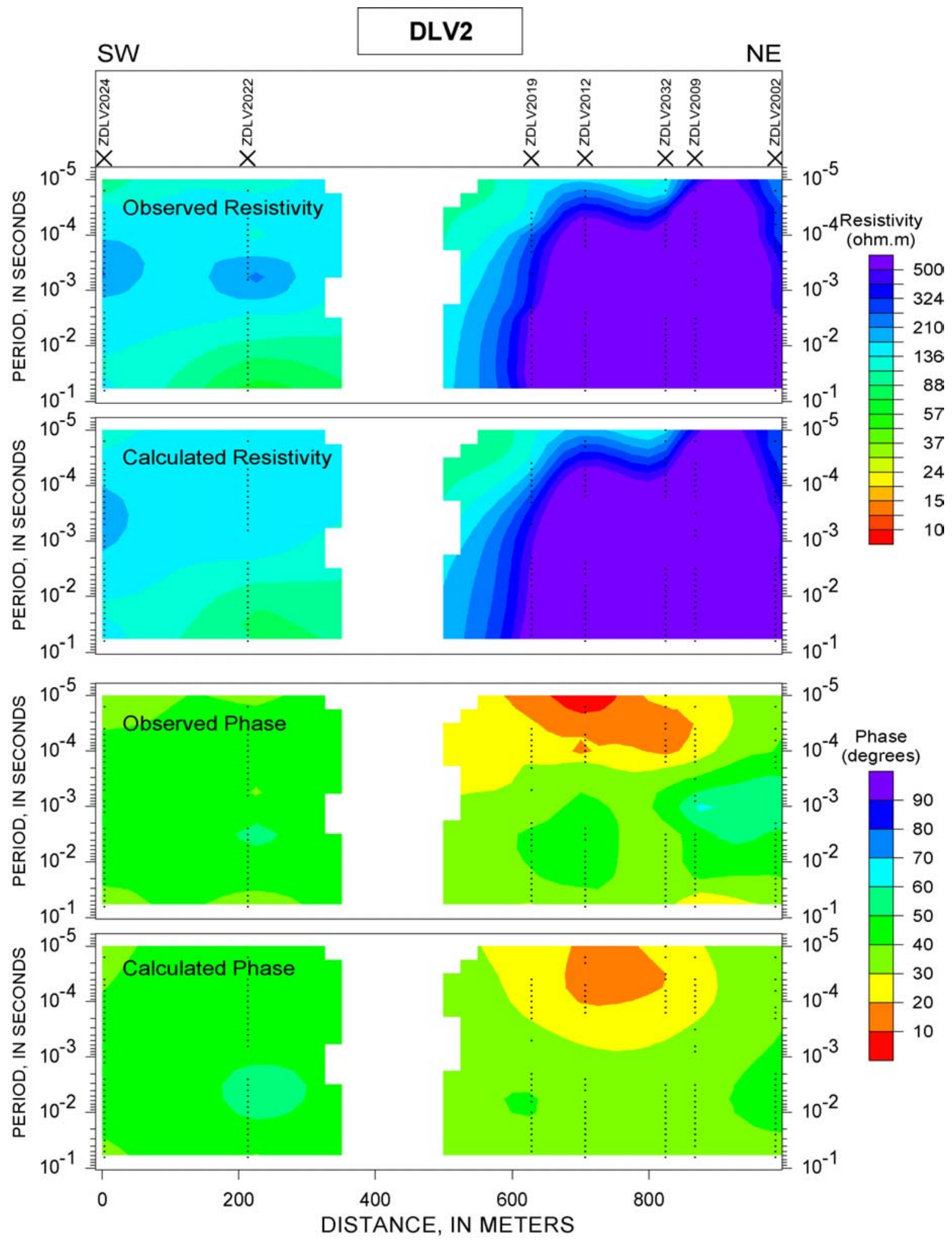

Figure 21. Pseudosections of observed data and model response for the apparent resistivity and phase along profile DLV2 in Dry Lake Valley, Nev. Black dots show data points. 


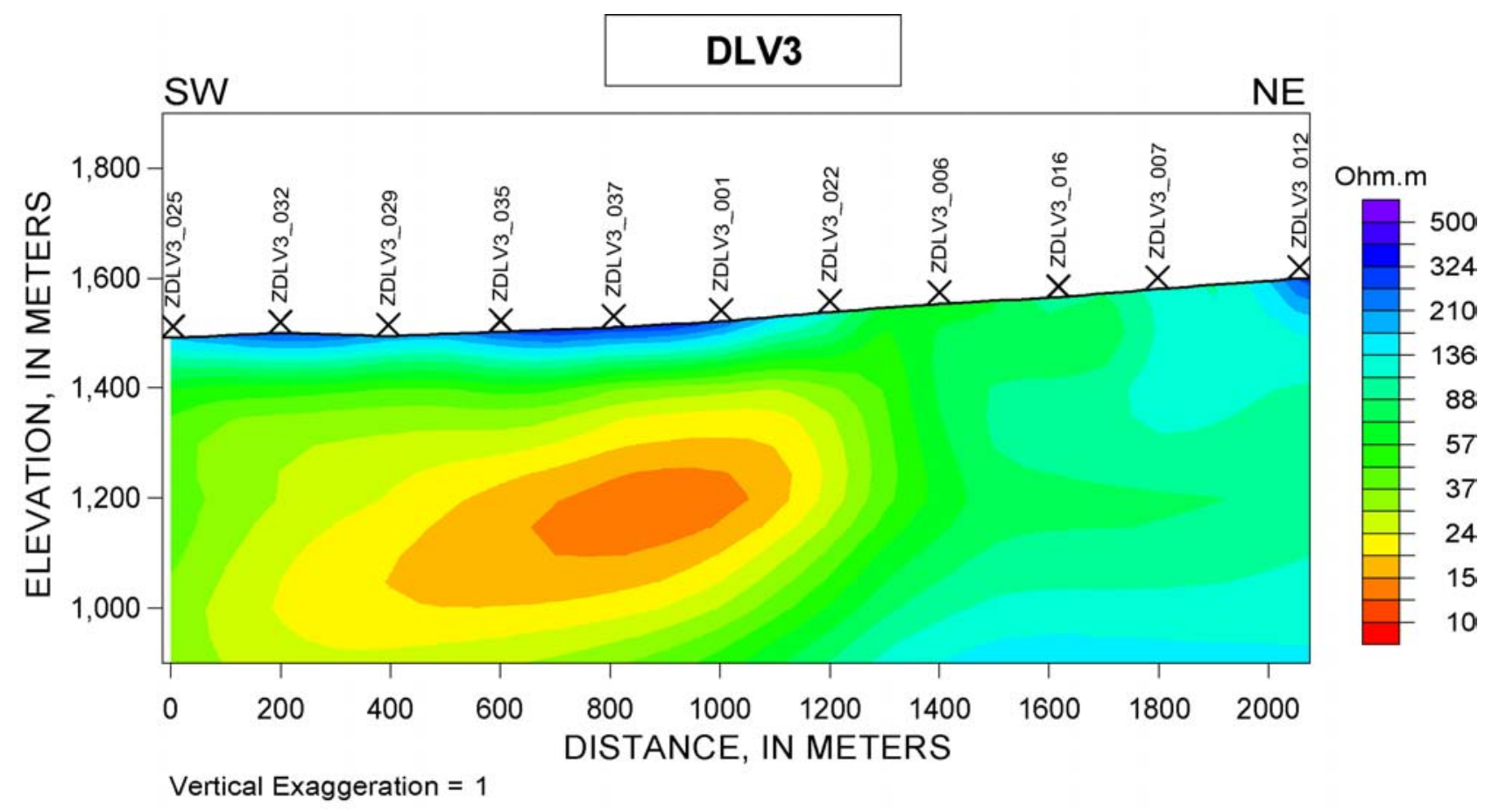

Figure 22. Two-dimensional inverse model computed from the transverse magneticmode data along profile DLV3 in Dry Lake Valley, Nev. RMS = 3.2. 


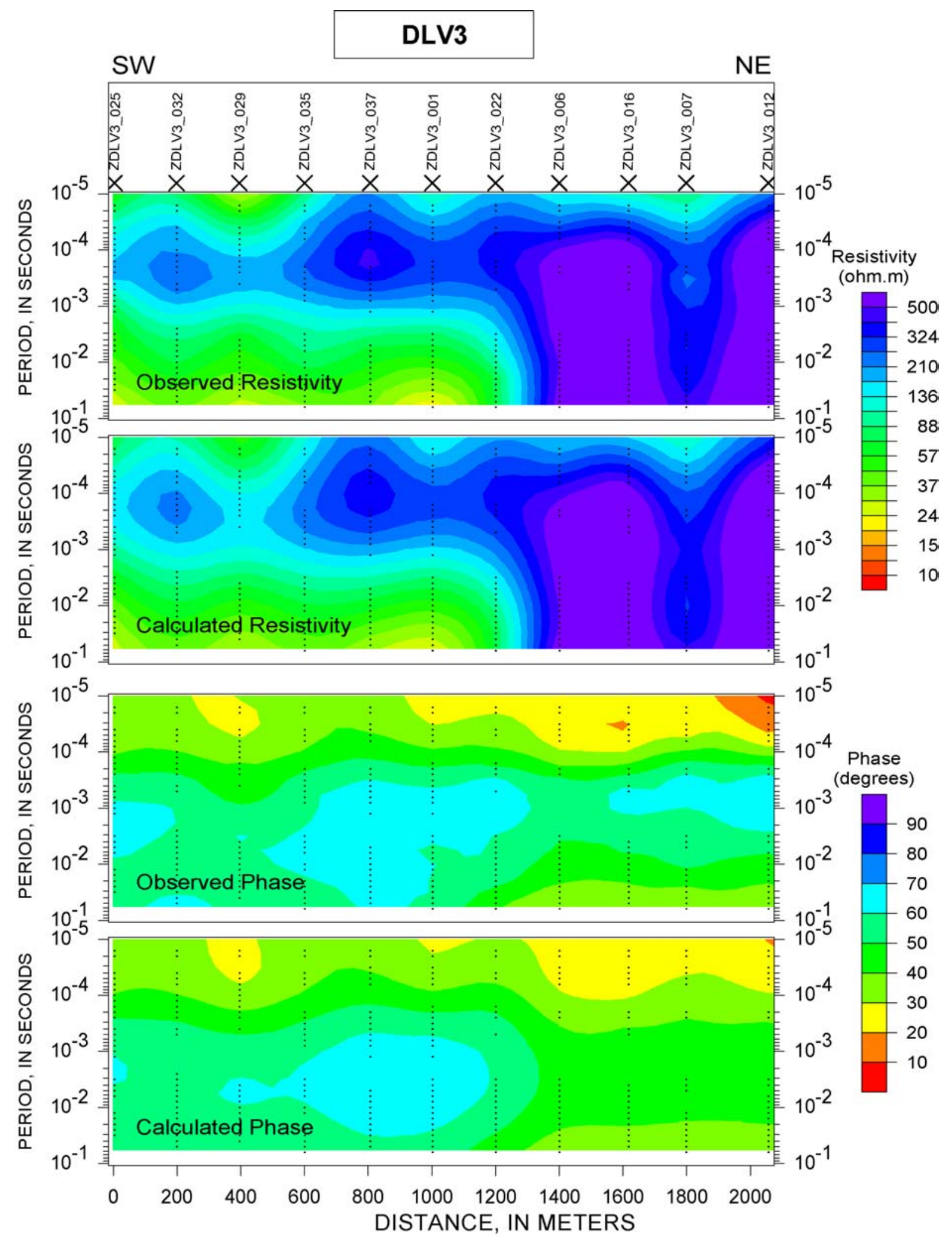

Figure 23. Pseudosections of observed data and model response for the apparent resistivity and phase along profile DLV3 in Dry Lake Valley, Nev. Black dots show data points. 


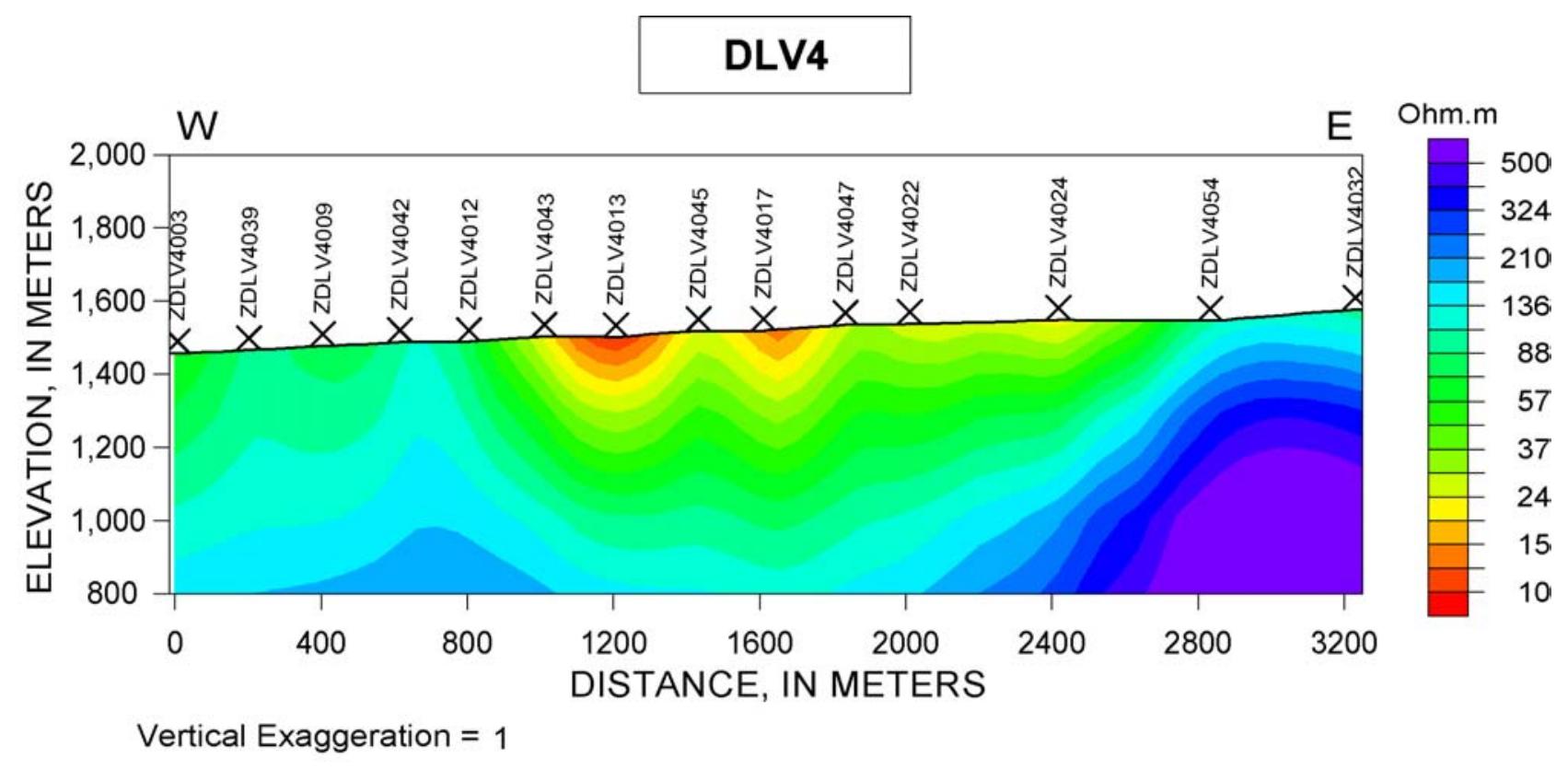

Figure 24. Two-dimensional inverse model computed from the transverse magneticmode data along profile DLV4 in Dry Lake Valley, Nev. RMS = 3.0. 




Figure 25. Pseudosections of observed data and model response for the apparent resistivity and phase along profile DLV4, Dry Lake Valley, Nev. Black dots show data points. 


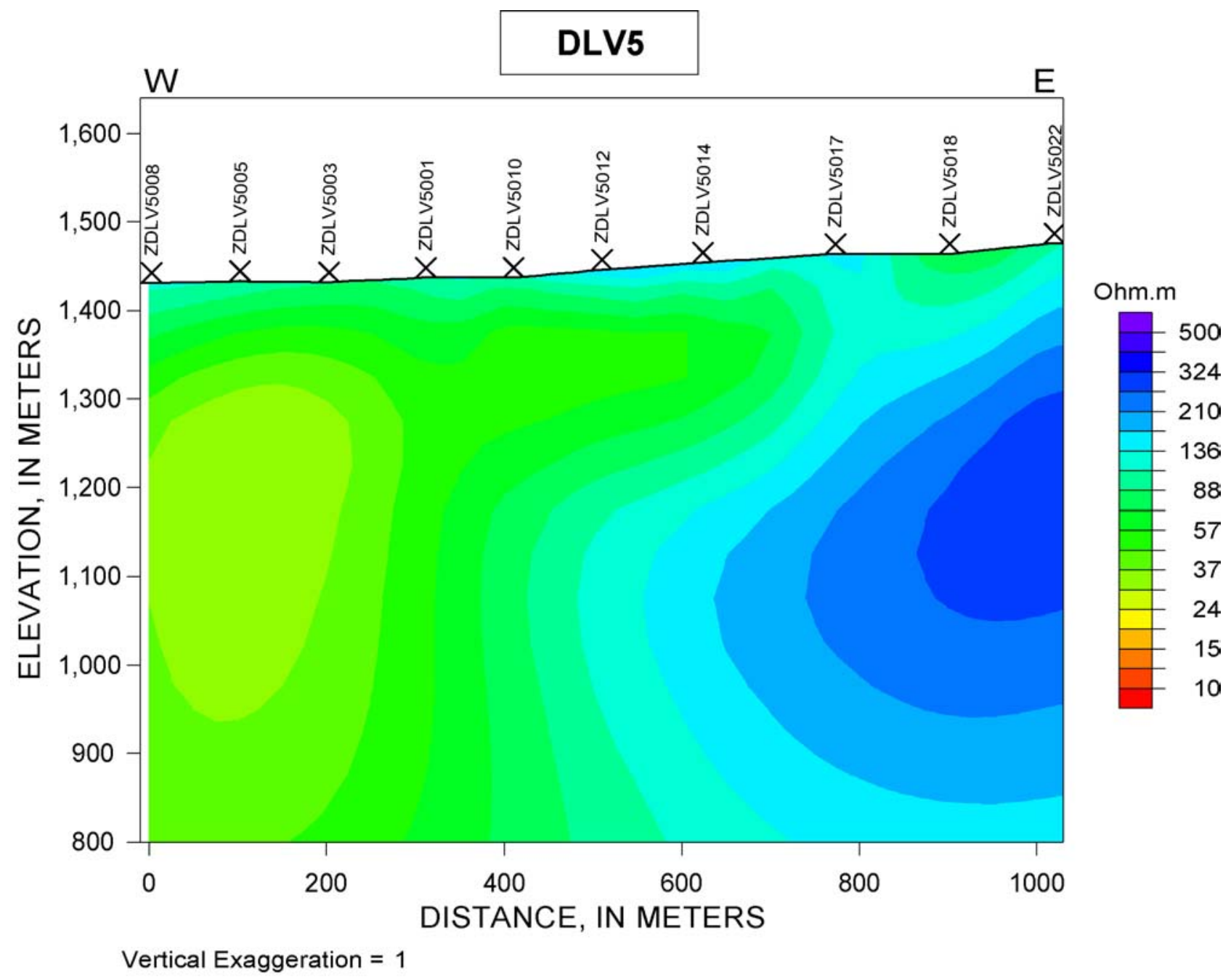

Figure 26. Two-dimensional inverse model computed from the transverse magneticmode data along profile DLV5 in Dry Lake Valley, Nev. RMS $=2.4$. 


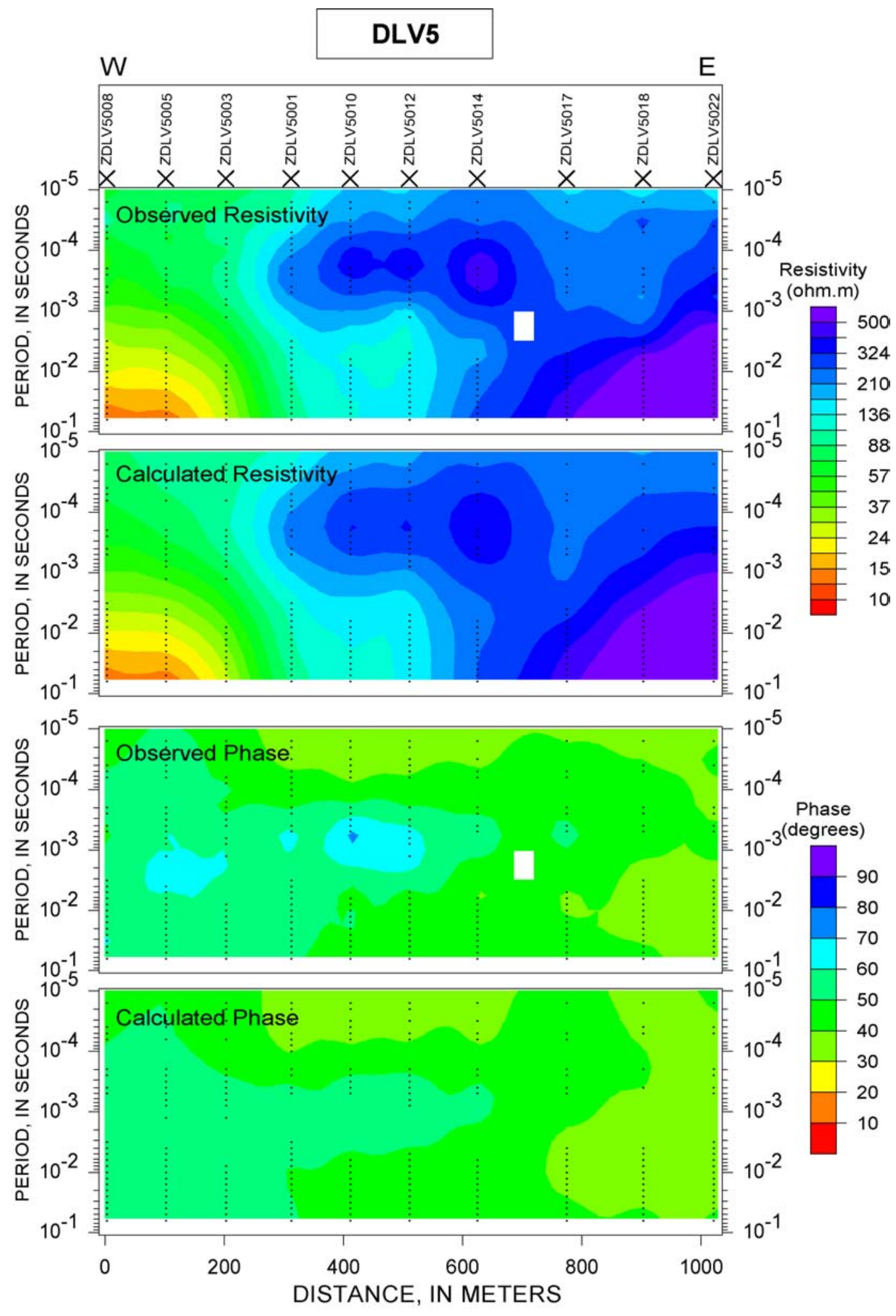

Figure 27. Pseudosections of observed data and model response for the apparent resistivity and phase along profile DLV5 in Dry Lake Valley, Nev. Black dots show data points. 


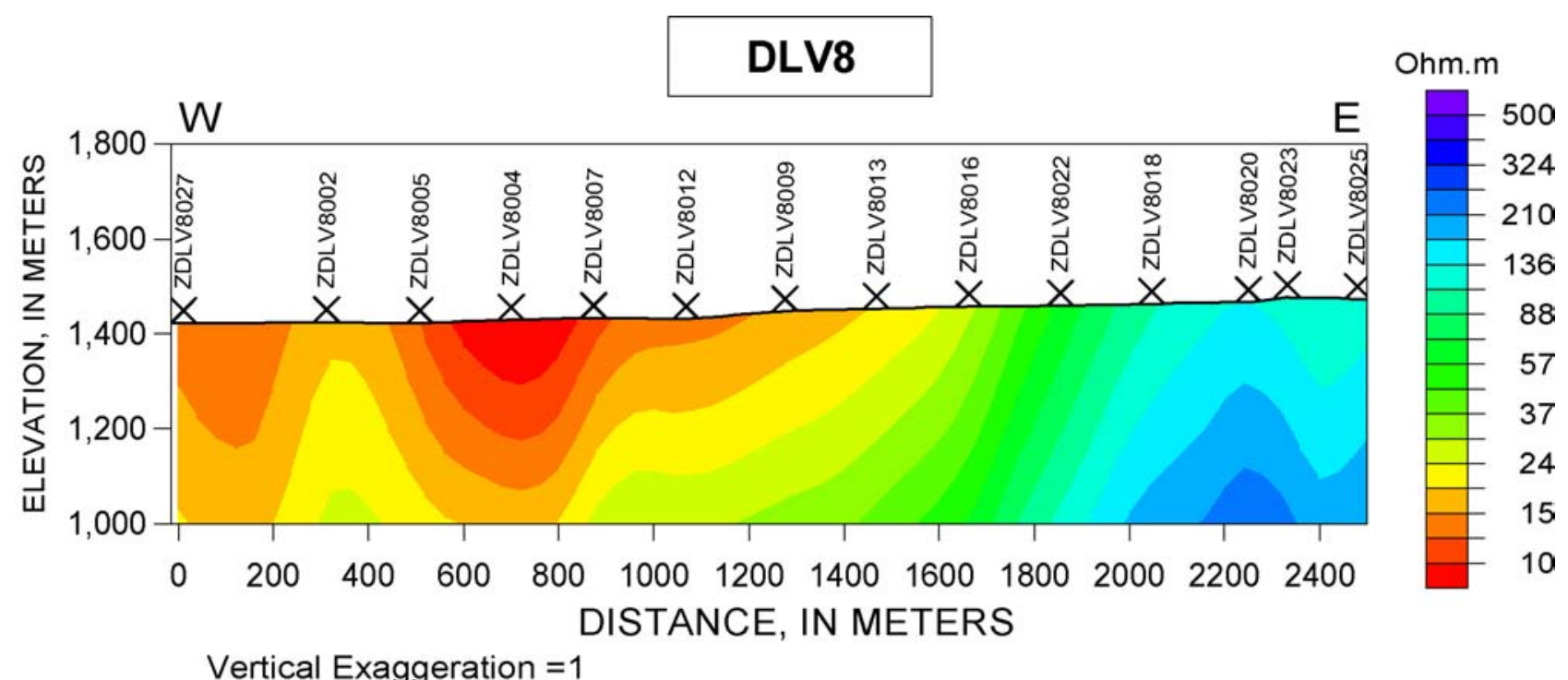

Figure 28. Two-dimensional inverse model computed from the transverse electric- and transverse magnetic-mode data along profile DLV8 in Dry Lake Valley, Nev. RMS = 3.0. 




A.
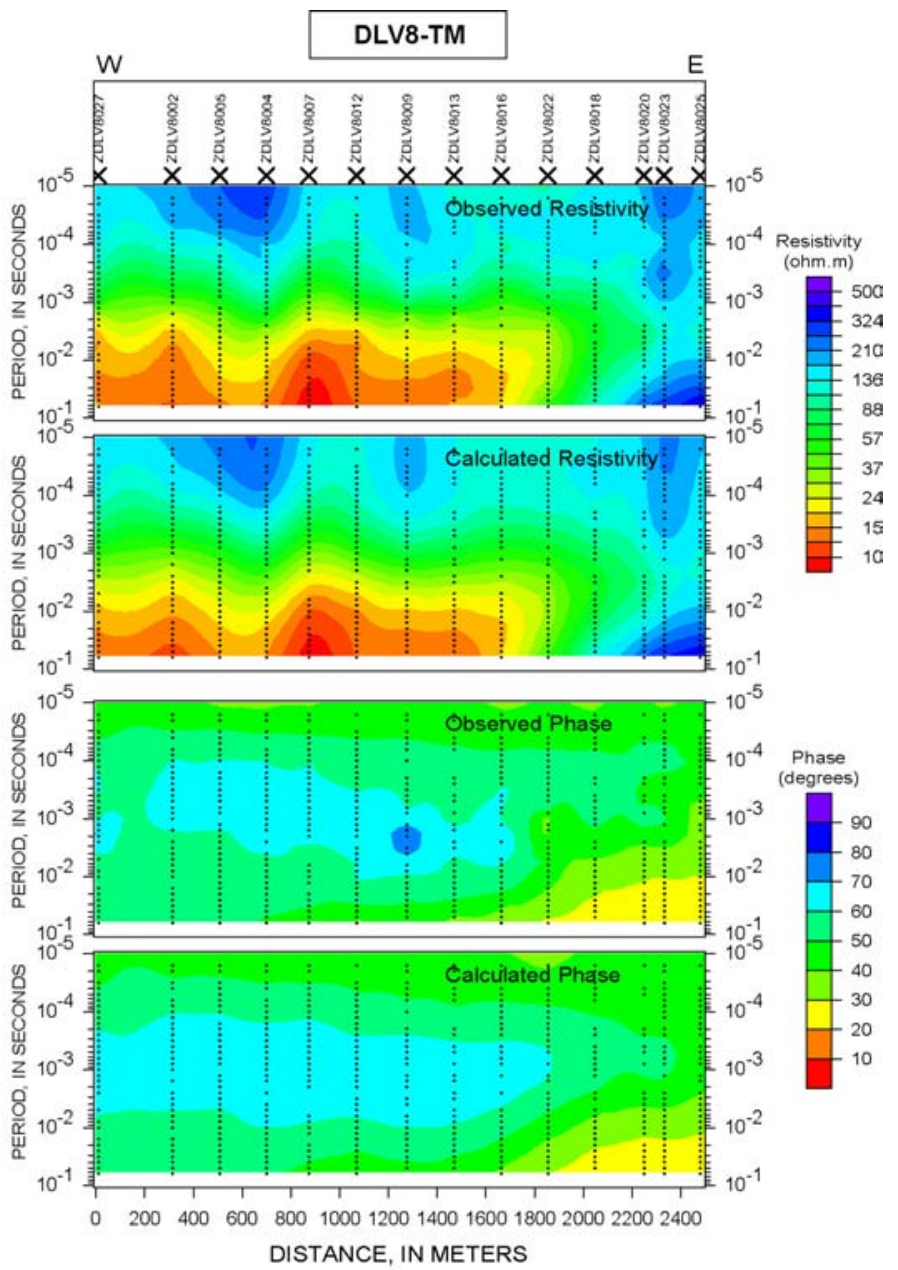

B.

Figure 29. Pseudosections of observed data and model response for the apparent resistivity and phase along profile DLV8 for both transverse electric- $(A)$ and transverse magnetic- (B) modes in Dry Lake Valley, Nev. Black dots show data points. 




Figure 30. Two-dimensional inverse model computed from the transverse magneticmode data along profile DLV24 in Dry Lake Valley, Nev. RMS = 2.6. 




Figure 31. Pseudosections of observed data and model response for the apparent resistivity and phase along profile DLV24 in Dry Lake Valley, Nev. Black dots show data points. 
Table 1. Description of audiomagnetotelluric profiles, Spring, Dry Lake, and Delamar Valleys, Nev.

[Profile azimuth in degrees relative to magnetic North (magnetic declination $\sim 13^{\circ}$ )]

\begin{tabular}{|l|r|r|r|r|l|}
\hline $\begin{array}{c}\text { Profile } \\
\text { name }\end{array}$ & $\begin{array}{c}\text { Length, in } \\
\text { Kilometers }\end{array}$ & $\begin{array}{c}\text { Profile } \\
\text { azimuth }\end{array}$ & $\begin{array}{c}\text { Station } \\
\text { spacing, in } \\
\text { meters }\end{array}$ & $\begin{array}{l}\text { Number of } \\
\text { stations }\end{array}$ & \multicolumn{1}{|c|}{ Comments } \\
\hline AQDCT & 2.8 & $50^{\circ}$ & 200 & 15 & $\begin{array}{l}\text { Eastern, central Spring Valley, } \\
\text { near Harbeck Aqueduct, data } \\
\text { collection led by SNWA }\end{array}$ \\
\hline SVNN & 2.4 & $80^{\circ}$ & 200 & 13 & $\begin{array}{l}\text { SE Spring Valley, NV, near } \\
\text { El Tejon Shoshone Spring, } \\
\text { data collection led by USGS }\end{array}$ \\
\hline SVNO & 0.8 & $30^{\circ}$ & 200 & 5 & $\begin{array}{l}\text { SE Spring Valley, NV, near Red } \\
\text { Ledges, data collection led by USGS }\end{array}$ \\
\hline SVNP & 2.8 & $80^{\circ}$ & 200 & 15 & $\begin{array}{l}\text { SE Spring Valley, NV, The Troughs, } \\
\text { data collection led by USGS }\end{array}$ \\
\hline SVNQ & 2.0 & $80^{\circ}$ & $100-200$ & 12 & $\begin{array}{l}\text { SE Spring Valley, Limestone Hills, } \\
\text { data collection led by USGS }\end{array}$ \\
\hline DELA1 & 1.2 & $140^{\circ}$ & 200 & 7 & $\begin{array}{l}\text { Southern Delamar Valley, NV, } \\
\text { data collection led by SNWA }\end{array}$ \\
\hline DELA5 & 0.7 & $160^{\circ}$ & $50-100$ & 11 & $\begin{array}{l}\text { Southern Delamar Valley, NV, } \\
\text { data collection led by SNWA }\end{array}$ \\
\hline DLV1 & 2.0 & $330^{\circ}$ & $100-200$ & 13 & $\begin{array}{l}\text { SE Dry Lake Valley, NV, } \\
\text { data collection led by USGS }\end{array}$ \\
\hline DLV2 & 1.0 & $20^{\circ}$ & $100-200$ & 8 & $\begin{array}{l}\text { Northern Dry Lake Valley, NV, } \\
\text { data collection led by USGS }\end{array}$ \\
\hline DLV3 & 2.1 & $50^{\circ}$ & 200 & 11 & $\begin{array}{l}\text { NE Dry Lake Valley, NV, } \\
\text { data collection led by USGS }\end{array}$ \\
\hline DLV4 & 3.2 & $90^{\circ}$ & $200-400$ & 14 & $\begin{array}{l}\text { Eastern Dry Lake Valley, NV, data } \\
\text { collection led by SNWA and USGS }\end{array}$ \\
\hline DLV5 & $\sim 1.0$ & $105^{\circ}$ & 100 & 10 & $\begin{array}{l}\text { Eastern Dry Lake Valley, NV, } \\
\text { data collection led by SNWA }\end{array}$ \\
\hline DLV8 & 2.5 & $80^{\circ}$ & $100-300$ & 14 & $\begin{array}{l}\text { Eastern Dry Lake Valley, NV, } \\
\text { data collection led by SNWA }\end{array}$ \\
\hline DLV24 & 1.4 & $340^{\circ}$ & 200 & 8 & $\begin{array}{l}\text { NW Dry Lake Valley, NV, } \\
\text { data collection led by SNWA }\end{array}$ \\
\hline
\end{tabular}


Table 2. Sounding numbers, locations, elevations and azimuths of stations along audiomagnetotelluric profiles, Spring, Dry Lake, and Delamar valleys, Nev.

[Numbers in station name refer to distance along profile in meters (Note that not all of the profiles begin at $0000 \mathrm{~m}$ ). Sounding is preferred sounding used in 2-D model. Horizontal locations are referenced to NAD 27, and Universal Transverse Mercator (zone 11N) units are in meters. Horizontal locations are accurate to approximately $3 \mathrm{~m}(10 \mathrm{ft})$


the orientation of the positive $\mathrm{x}$-component relative to magnetic North (magnetic declination $\sim 13^{\circ}$ ).]

\begin{tabular}{|c|c|c|c|c|c|c|}
\hline Station & Sounding & $\begin{array}{l}\text { Easting, } \\
\text { in meters }\end{array}$ & $\begin{array}{l}\text { Northing, } \\
\text { in meters }\end{array}$ & $\begin{array}{l}\text { Elevation, } \\
\text { in feet }\end{array}$ & $\begin{array}{l}\text { Elevation, } \\
\text { in meters }\end{array}$ & $\begin{array}{c}\mathrm{X} \text { azimuth, } \\
\text { degrees }\end{array}$ \\
\hline \multicolumn{7}{|c|}{ AQDCT } \\
\hline SVAQDCT0000 & 001 & 725807 & 4318981 & 6,659 & 2,030 & 50 \\
\hline SVAQDCT0200 & $\begin{array}{l}\text { 024(removed } \\
\text { due to noise) }\end{array}$ & 725528 & 4318810 & 6,563 & 2,001 & 50 \\
\hline SVAQDCT0400 & 004 & 725346 & 4318651 & 6,491 & 1,979 & 50 \\
\hline SVAQDCT0600 & 025 & 725190 & 4318506 & 6,452 & 1,967 & 50 \\
\hline SVAQDCT0800 & 005 & 724964 & 4318477 & 6,386 & 1,947 & 50 \\
\hline SVAQDCT1000 & 028 & 724765 & 4318465 & 6,337 & 1,932 & 50 \\
\hline SVAQDCT1200 & 008 & 724580 & 4318396 & 6,288 & 1,917 & 50 \\
\hline SVAQDCT1400 & 022 & 724360 & 4318368 & 6,232 & 1,900 & 50 \\
\hline SVAQDCT1600 & 009 & 724191 & 4318223 & 6,183 & 1,885 & 50 \\
\hline SVAQDCT1800 & 021 & 723972 & 4318192 & 6,134 & 1,870 & 50 \\
\hline SVAQDCT2000 & 013 & 723823 & 4318067 & 6,084 & 1,855 & 50 \\
\hline SVAQDCT2200 & 020 & 723624 & 4317968 & 6,038 & 1,841 & 50 \\
\hline SVAQDCT2400 & 014 & 723437 & 4317895 & 6,015 & 1,834 & 50 \\
\hline SVAQDCT2600 & 018 & 723228 & 4317805 & 5,976 & 1,822 & 50 \\
\hline SVAQDCT2800 & 016 & 723039 & 4317775 & 5,950 & 1,814 & 50 \\
\hline \multicolumn{7}{|c|}{ SVNN } \\
\hline SVNN0200 & 047 & 726985 & 4303072 & 5,290 & 1,805 & 125 \\
\hline SVNN0400 & 035 & 727183 & 4303062 & 5,927 & 1,807 & 80 \\
\hline SVNN0600 & 039 & 727381 & 4303038 & 5,966 & 1,819 & 80 \\
\hline SVNN0800 & 032 & 727585 & 4303057 & 5,983 & 1,824 & 80 \\
\hline SVNN1000 & 014 & 727793 & 4303084 & 5,996 & 1,828 & 80 \\
\hline SVNN1200 & 027 & 727993 & 4303121 & 6,009 & 1,832 & 80 \\
\hline SVNN1400 & 012 & 728191 & 4303120 & 6,032 & 1,839 & 80 \\
\hline SVNN1600 & $\begin{array}{l}\text { 023(removed } \\
\text { due to noise) }\end{array}$ & 728400 & 4303085 & 6,081 & 1,854 & 80 \\
\hline SVNN1800 & 007 & 728514 & 4302886 & 6,081 & 1,854 & 80 \\
\hline SVNN2000 & 021 & 728659 & 4302728 & 6,101 & 1,860 & 80 \\
\hline SVNN2200 & 004 & 728860 & 4302658 & 6,140 & 1,872 & 80 \\
\hline SVNN2400 & 017 & 729089 & 4302681 & 6,225 & 1,898 & 80 \\
\hline
\end{tabular}




\begin{tabular}{|c|c|c|c|c|c|c|}
\hline SVNN2600 & \begin{tabular}{|l|}
001 \\
\end{tabular} & 729245 & 4302561 & 6,134 & 1,870 & 80 \\
\hline \multicolumn{7}{|c|}{ SVNO } \\
\hline SVNO0400 & \begin{tabular}{|l|}
007 \\
\end{tabular} & 736989 & 4279878 & 6,283 & 1,915 & 30 \\
\hline SVNO0600 & 003 & 736877 & 4279741 & 6,125 & 1,867 & 30 \\
\hline SVNO0800 & 009 & 736738 & 4279601 & 6,089 & 1,856 & 30 \\
\hline SVNO1000 & 002 & 736620 & 4279441 & 6,060 & 1,847 & 30 \\
\hline SVNO1200 & 011 & 736492 & 4279293 & 6,050 & 1,844 & 30 \\
\hline \multicolumn{7}{|c|}{ SVNP } \\
\hline SVNP0000 & 037 & 738614 & 4279195 & 6,073 & 1,851 & 80 \\
\hline SVNP0200 & \begin{tabular}{|l}
036 \\
\end{tabular} & 738377 & 4279164 & 6,053 & 1,845 & 80 \\
\hline SVNP0400 & 003 & 738210 & 4279054 & 6,047 & 1,843 & 80 \\
\hline SVNP0600-2 & \begin{tabular}{|l|}
022 \\
\end{tabular} & 738030 & 4279094 & 6,066 & 1,849 & 80 \\
\hline SVNP0800 & 005 & 737841 & 4279123 & 6,033 & 1,839 & 80 \\
\hline SVNP1000 & 019 & 737617 & 4279035 & 6,043 & 1,842 & 80 \\
\hline SVNP1200 & \begin{tabular}{|l|}
008 \\
\end{tabular} & 737449 & 4279049 & 6,043 & 1,842 & 80 \\
\hline SVNP1400 & 023 & 737234 & 4279028 & 6,043 & 1,842 & 80 \\
\hline SVNP1600 & \begin{tabular}{|l|}
009 \\
\end{tabular} & 737029 & 4279025 & 6,047 & 1,843 & 80 \\
\hline SVNP1800 & 025 & 736827 & 4279041 & 6,047 & 1,843 & 80 \\
\hline SVNP2000 & 012 & 736631 & 4279029 & 6,043 & 1,842 & 80 \\
\hline SVNP2200 & \begin{tabular}{|l|}
028 \\
\end{tabular} & 736429 & 4279032 & 6,033 & 1,839 & 80 \\
\hline SVNP2400 & 014 & 736230 & 4279033 & 6,050 & 1,844 & 80 \\
\hline SVNP2600 & \begin{tabular}{|l|}
029 \\
\end{tabular} & 736026 & 4279045 & 6,070 & 1,850 & 80 \\
\hline SVNP2800 & 032 & 735828 & 4279022 & 6,066 & 1,849 & 80 \\
\hline \multicolumn{7}{|c|}{ SVNQ } \\
\hline SVNQ0250 & 012 & 736750 & 4272617 & 6,375 & 1,943 & 125 \\
\hline SVNQ0400 & 014 & 736609 & 4272633 & 6,335 & 1,931 & 80 \\
\hline SVNQ0500 & \begin{tabular}{|l|}
017 \\
\end{tabular} & 736510 & 4272639 & 6,312 & 1,924 & 80 \\
\hline SVNQ0600 & 007 & 736411 & 4272645 & 6,289 & 1,917 & 80 \\
\hline SVNQ0800 & 009 & 736209 & 4272648 & 6,250 & 1,905 & 80 \\
\hline SVNQ1000 & \begin{tabular}{|l|}
004 \\
\end{tabular} & 736012 & 4272671 & 6,211 & 1,893 & 80 \\
\hline SVNQ1200 & 020 & 735795 & 4272649 & 6,198 & 1,889 & 80 \\
\hline SVNQ1400 & \begin{tabular}{|l|}
002 \\
\end{tabular} & 735608 & 4272654 & 6,175 & 1,882 & 80 \\
\hline SVNQ1600 & 023 & 735382 & 4272675 & 6,158 & 1,877 & 80 \\
\hline SVNQ1800 & 025 & 735182 & 4272655 & 6,122 & 1,866 & 80 \\
\hline SVNQ2000 & \begin{tabular}{|l|}
033 \\
\end{tabular} & 734980 & 4272661 & 6,106 & 1,861 & 80 \\
\hline SVNQ2200 & \begin{tabular}{|l|}
029 \\
\end{tabular} & 734782 & 4272676 & 6,099 & 1,859 & 80 \\
\hline \multicolumn{7}{|c|}{ DELA1 } \\
\hline DELA10000 & 003 & 682368 & 4124768 & 4,814 & 1,467 & 140 \\
\hline DELA10200 & \begin{tabular}{|l|}
007 \\
\end{tabular} & 682283 & 4124930 & 4,763 & 1,452 & 140 \\
\hline DELA10400 & 006 & 682192 & 4125093 & 4,735 & 1,443 & 140 \\
\hline DELA10600 & \begin{tabular}{|l|}
001 \\
\end{tabular} & 682092 & 4125281 & 4,701 & 1,433 & 140 \\
\hline DELA10800 & 012 & 681996 & 4125444 & 4,673 & 1,424 & 140 \\
\hline DELA11000 & \begin{tabular}{|l|}
010 \\
\end{tabular} & 681897 & 4125595 & 4,657 & 1,419 & 140 \\
\hline DELA11200 & \begin{tabular}{|l}
$\begin{array}{l}\text { omitted due } \\
\text { to noise }\end{array}$ \\
\end{tabular} & 681771 & 4125771 & 4,639 & 1,414 & 140 \\
\hline
\end{tabular}




\begin{tabular}{|c|c|c|c|c|c|c|}
\hline \multicolumn{7}{|c|}{ DELA5 } \\
\hline DELA50000 & 009 & 680753 & 4129335 & 4,624 & 1,409 & 160 \\
\hline DELA50050 & 008 & 680734 & 4129382 & 4,625 & 1,410 & 160 \\
\hline DELA50100 & 005 & 680715 & 4129430 & 4,622 & 1,409 & 160 \\
\hline DELA50150 & 001 & 680699 & 4129479 & 4,628 & 1,410 & 160 \\
\hline DELA50200 & 013 & 680680 & 4129523 & 4,623 & 1,409 & 160 \\
\hline DELA50250 & 017 & 680661 & 4129571 & 4,626 & 1,410 & 160 \\
\hline DELA50300 & 018 & 680642 & 4129620 & 4,619 & 1,408 & 160 \\
\hline DELA5A0400 & 002 & 680604 & 4129716 & 4,613 & 1,406 & 160 \\
\hline DELA5A0500 & 004 & 680568 & 4129813 & 4,600 & 1,402 & 160 \\
\hline DELA5A0600 & 012 & 680528 & 4129910 & 4,583 & 1,397 & 160 \\
\hline DELA5A0700 & 009 & 680497 & 4129997 & 4,685 & 1,428 & 160 \\
\hline \multicolumn{7}{|c|}{ DLV1 } \\
\hline DLV10000 & 017 & 700110 & 4170386 & 5,066 & 1,544 & 330 \\
\hline DLV10100 & 018 & 700030 & 4170341 & 5,069 & 1,545 & 330 \\
\hline DLV10250 & 021 & 699875 & 4170275 & 5,066 & 1,544 & 330 \\
\hline DLV10400 & 013 & 699717 & 4170363 & 5,033 & 1,534 & 330 \\
\hline DLV10600 & 014 & \begin{tabular}{|l|}
699527 \\
\end{tabular} & 4170444 & 5,013 & 1,528 & 330 \\
\hline DLV10800 & 010 & 699322 & 4170490 & 5,010 & 1,527 & 285 \\
\hline DLV11000 & 003 & 699117 & 4170523 & 4,977 & 1,517 & 285 \\
\hline DLV11200 & 008 & \begin{tabular}{|l|}
698928 \\
\end{tabular} & 4170547 & 4,954 & 1,510 & 285 \\
\hline DLV11300 & 031 & \begin{tabular}{|l|}
698822 \\
\end{tabular} & 4170585 & 4,951 & 1,509 & 330 \\
\hline DLV11400 & \begin{tabular}{|l|}
004 \\
\end{tabular} & \begin{tabular}{|l|}
698666 \\
\end{tabular} & 4170601 & \begin{tabular}{|l|}
4,918 \\
\end{tabular} & 1,499 & 285 \\
\hline DLV11600 & 024 & 698556 & 4170695 & 4,925 & 1,501 & 330 \\
\hline DLV11800 & 029 & 698339 & 4170772 & 4,902 & 1,494 & 330 \\
\hline DLV12000 & 027 & \begin{tabular}{|l|}
698125 \\
\end{tabular} & 4170818 & 4,869 & 1,484 & 330 \\
\hline \multicolumn{7}{|c|}{ DLV2 } \\
\hline DLV20000 & 002 & \begin{tabular}{|l|}
697945 \\
\end{tabular} & 4219638 & 5,315 & 1,620 & 20 \\
\hline DLV20100 & 009 & \begin{tabular}{|l|}
697902 \\
\end{tabular} & 4219526 & 5,285 & 1,611 & 20 \\
\hline DLV20200 & 032 & \begin{tabular}{|l|}
697883 \\
\end{tabular} & 4219489 & 5,279 & 1,609 & 20 \\
\hline DLV20300 & 012 & 697818 & 4219388 & 5,253 & 1,601 & 20 \\
\hline DVL20400 & \begin{tabular}{|l|}
019 \\
\end{tabular} & \begin{tabular}{|l}
697794 \\
\end{tabular} & 4219310 & 5,249 & 1,600 & 20 \\
\hline DVL20600 & $\begin{array}{l}025 \text { (removed } \\
\text { due to 3-D } \\
\text { effects) }\end{array}$ & 697633 & 4219147 & 5,194 & 1,583 & 20 \\
\hline DLV20800 & 022 & \begin{tabular}{|l|l|}
697532 \\
\end{tabular} & 4218985 & 5,194 & 1,583 & 20 \\
\hline DLV21000 & 024 & 697417 & 4218809 & 5,177 & 1,578 & 20 \\
\hline \multicolumn{7}{|c|}{ DLV3 } \\
\hline DLV31000 & 012 & \begin{tabular}{|l|l}
701495 \\
\end{tabular} & 4213491 & 5,246 & 1,599 & 50 \\
\hline DLV31200 & 007 & 701239 & 4213421 & 5,184 & 1,580 & 50 \\
\hline DLV31400 & 016 & 701085 & 4213326 & 5,135 & 1,565 & 50 \\
\hline DLV31600 & 006 & 700889 & 4213231 & 5,095 & 1,553 & 50 \\
\hline DLV31800 & 022 & 700721 & 4213124 & 5,046 & 1,538 & 50 \\
\hline DLV32000 & 001 & \begin{tabular}{|l|}
700544 \\
\end{tabular} & 4213034 & 4,990 & 1,521 & 50 \\
\hline DLV32200 & 037 & 700376 & 4212934 & 4,954 & 1,510 & 50 \\
\hline
\end{tabular}




\begin{tabular}{|c|c|c|c|c|c|c|}
\hline DLV32400 & 035 & 700200 & 4212826 & 4,928 & 1,502 & 50 \\
\hline DLV32600 & 029 & 700020 & 4212729 & 4,902 & 1,494 & 50 \\
\hline DLV32800 & 032 & 699854 & 4212623 & 4,921 & 1,500 & 50 \\
\hline DLV33000 & 025 & 699678 & 4212536 & 4,892 & 1,491 & 50 \\
\hline \multicolumn{7}{|c|}{ DLV4 } \\
\hline DLV40000 & 003 & 701074 & 4195706 & 4,777 & 1,456 & 90 \\
\hline DLV40200 & 039 & 701279 & 4195696 & 4,808 & 1,465 & 90 \\
\hline DLV40400 & 009 & 701465 & 4195615 & 4,843 & 1,476 & 90 \\
\hline DLV40600 & 042 & 701668 & 4195558 & 4,876 & 1,486 & 90 \\
\hline DLV40800 & 012 & 701840 & 4195477 & 4,882 & 1,488 & 90 \\
\hline DLV41000 & 043 & 702035 & 4195407 & 4,927 & 1,502 & 90 \\
\hline DLV41200 & 013 & 702210 & 4195321 & 4,925 & 1,501 & 90 \\
\hline DLV41400 & 045 & 702427 & 4195251 & 4,979 & 1,518 & 90 \\
\hline DLV41600 & 017 & 702591 & 4195181 & 4,980 & 1,518 & 90 \\
\hline DLV41800 & 047 & 702821 & 4195160 & 5,037 & 1,535 & 90 \\
\hline DLV42000 & 022 & 702981 & 4195086 & 5,039 & 1,536 & 90 \\
\hline DLV42400 & 024 & 703369 & 4194959 & 5,075 & 1,547 & 90 \\
\hline DLV42800 & 054 & 703743 & 4194818 & 5,128 & 1,563 & 90 \\
\hline DLV43200 & 036 & 704109 & 4194619 & 5,174 & 1,577 & 90 \\
\hline \multicolumn{7}{|c|}{ DLV5 } \\
\hline DLV50400 & 022 & 701824 & 4199252 & 4,843 & 1,476 & 150 \\
\hline DLV50500 & 018 & 701709 & 4199277 & 4,803 & 1,464 & 105 \\
\hline DLV50600 & 017 & 701582 & 4199297 & 4,803 & 1,464 & 105 \\
\hline DLV50700 & 014 & 701438 & 4199343 & 4,770 & 1,454 & 105 \\
\hline DLV50800 & 012 & 701323 & 4199344 & 4,774 & 1,446 & 105 \\
\hline DLV50900 & 010 & 701221 & 4199339 & 4,715 & 1,437 & 150 \\
\hline DLV51000 & 001 & 701121 & 4199343 & 4,715 & 1,437 & 105 \\
\hline DLV51100 & 003 & 701016 & 4199375 & 4,698 & 1,432 & 105 \\
\hline DLV51200 & 005 & 700918 & 4199400 & 4,701 & 1,433 & 105 \\
\hline DLV51300 & 008 & 700822 & 4199427 & 4,695 & 1,431 & 150 \\
\hline \multicolumn{7}{|c|}{ DLV8 } \\
\hline DLV8-200 & 025 & 701202 & 4185973 & 4,836 & 1,474 & 80 \\
\hline DLV8-100 & 023 & 701052 & 4185972 & 4,843 & 1,476 & 80 \\
\hline DLV80000 & 020 & 700982 & 4186056 & 4,813 & 1,467 & 80 \\
\hline DLV80200 & 018 & 700786 & 4186110 & 4,800 & 1,463 & 80 \\
\hline DLV80400 & 022 & 700588 & 4186091 & 4,787 & 1,459 & 80 \\
\hline DLV80600 & 016 & 700396 & 4186103 & 4,780 & 1,457 & 80 \\
\hline DLV80800 & 013 & 700203 & 4186128 & 4,767 & 1,453 & 80 \\
\hline DLV81000 & 009 & 700014 & 4186171 & 4,751 & 1,448 & 80 \\
\hline DLV81200 & 012 & 699817 & 4186250 & 4,695 & 1,431 & 80 \\
\hline DLV81400 & 007 & 699619 & 4186243 & 4,705 & 1,434 & 80 \\
\hline DLV81600 & 004 & 699444 & 4186250 & 4,688 & 1,429 & 80 \\
\hline DLV81800 & 005 & 699262 & 4186330 & 4,669 & 1,423 & 80 \\
\hline DLV82000 & 002 & 699061 & 4186306 & 4,672 & 1,424 & 80 \\
\hline DLV82300 & 027 & 698754 & 4186299 & 4,669 & 1,423 & 80 \\
\hline
\end{tabular}




\begin{tabular}{|l|l|l|l|l|l|l|}
\hline \multicolumn{7}{|l|}{ DLV24 } \\
\hline \multicolumn{7}{|l|}{$\mid$} \\
\hline DLV240000 & 004 & 691392 & 4210725 & 4,915 & 1,498 & 340 \\
\hline DLV240200 & 008 & 691206 & 4210856 & 4,948 & 1,508 & 340 \\
\hline DLV240400 & 006 & 691017 & 4210870 & 4,961 & 1,512 & 340 \\
\hline DLV240600 & 010 & 690836 & 4211007 & 4,948 & 1,519 & 340 \\
\hline DLV240800 & 012 & 690622 & 4210994 & 4,993 & 1,522 & 340 \\
\hline DLV241000 & 018 & 690439 & 4211081 & 5,000 & 1,524 & 340 \\
\hline DLV241200 & 014 & 690233 & 4211080 & 5,036 & 1,535 & 340 \\
\hline DLV241400 & 016 & 690042 & 4211104 & 5,030 & 1,533 & 340 \\
\hline
\end{tabular}

\section{Appendix}

\section{A. Sounding curves.}

The Audiomagnetotelluric Data section in this report contains an explanation of three separate plots for each station:

1. Apparent Resistivity curves with $\mathrm{x}$-directed along profile such that the nominal TM mode is ExHy (red diamond) and TE is EyHx (blue square).

2. Impedance Phase curves with $\mathrm{x}$-directed along profile such that the nominal TM mode is ExHy (red diamond) and TE is EyHx (blue square).

3. Multiple E-Predicted Coherencies, defined as (ExHy * Conj(ExHy)) / (Hy * Conj(Hy) * Ex * Conj(Ex)) (red diamond) and $(\mathrm{EyHx} * \mathrm{Conj}(\mathrm{EyHx})) /(\mathrm{Hx} * \mathrm{Conj}(\mathrm{Hx}) *$ Ey * Conj(Ey)) (blue square)

Conj indicates complex conjugation. Sounding curves are named by profile name and distance along the profile $(\mathrm{m})$.

\section{B. Conversion Factors}

\begin{tabular}{llll}
\hline & Multiply & By & To obtain \\
\hline inch (in.) & 2.54 & & centimeter $(\mathrm{cm})$ \\
\hline
\end{tabular}




\begin{tabular}{lll}
\hline foot $(\mathrm{ft})$ & 0.3048 & meter $(\mathrm{m})$ \\
\hline mile $(\mathrm{mi})$ & 1.609 & kilometer $(\mathrm{km})$ \\
\hline centimeter $(\mathrm{cm})$ & 0.3937 & inch (in.) \\
\hline meter $(\mathrm{m})$ & 3.281 & foot $(\mathrm{ft})$ \\
\hline kilometer $(\mathrm{km})$ & 0.6214 & mile $(\mathrm{mi})$ \\
\hline $\begin{array}{l}\text { kilogram per cubic meter } \\
\left(\mathrm{kg} / \mathrm{m}^{3}\right)\end{array}$ & 0.06242 & pound per cubic foot $\left(\mathrm{lb} / \mathrm{ft}^{3}\right)$ \\
\hline
\end{tabular}

Vertical coordinate information is referenced to the North American Vertical Datum of 1929 (NAVD29). Horizontal coordinate information is referenced to the North American Datum of 1927 (NAD27). 